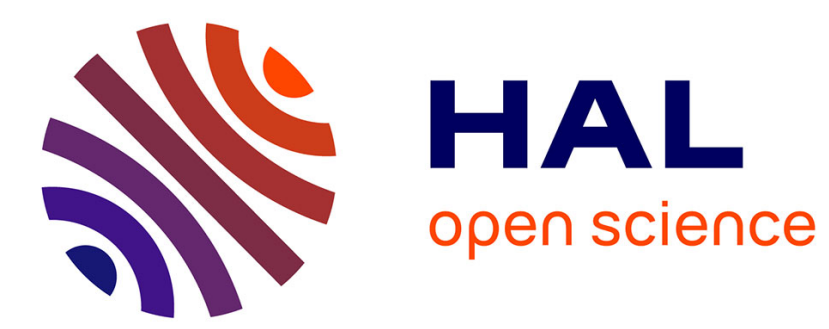

\title{
The spectrum of hypermotor seizures: a pragmatic approach
}

Élodie Lamétéry

\section{To cite this version:}

Élodie Lamétéry. The spectrum of hypermotor seizures: a pragmatic approach. Human health and pathology. 2015. dumas-01213672

\section{HAL Id: dumas-01213672 https://dumas.ccsd.cnrs.fr/dumas-01213672}

Submitted on 8 Oct 2015

HAL is a multi-disciplinary open access archive for the deposit and dissemination of scientific research documents, whether they are published or not. The documents may come from teaching and research institutions in France or abroad, or from public or private research centers.
L'archive ouverte pluridisciplinaire HAL, est destinée au dépôt et à la diffusion de documents scientifiques de niveau recherche, publiés ou non, émanant des établissements d'enseignement et de recherche français ou étrangers, des laboratoires publics ou privés. 


\section{Joseph Fourier 7 F MEDECINE}

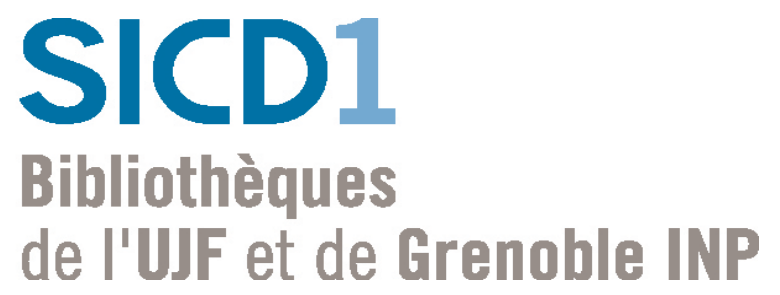

\section{AVERTISSEMENT}

Ce document est le fruit d'un long travail approuvé par le jury de soutenance et mis à disposition de l'ensemble de la communauté universitaire élargie.

Il n'a pas été réévalué depuis la date de soutenance.

Il est soumis à la propriété intellectuelle de l'auteur. Ceci implique une obligation de citation et de référencement lors de l'utilisation de ce document.

D'autre part, toute contrefaçon, plagiat, reproduction illicite encourt une poursuite pénale.

Contact au SICD1 de Grenoble : thesebum@ujf-grenoble.fr

\section{LIENS}

Code de la Propriété Intellectuelle. articles L 122. 4 Code de la Propriété Intellectuelle. articles L 335.2- L 335.10 http://www.cfcopies.com/juridique/droit-auteur http://www.culture.gouv.fr/culture/infos-pratiques/droits/protection.htm 
UNIVERSITE JOSEPH FOURIER

FACULTE DE MEDECINE DE GRENOBLE

Année 2015

\title{
The spectrum of hypermotor seizures: a pragmatic approach
}

\author{
THESE \\ PRESENTEE POUR L'OBTENTION DU DOCTORAT EN MEDECINE \\ DIPLÔME D’ETAT
}

Elodie Lamétéry

Née le 10/08/1987 à Feurs (42)

THESE SOUTENUE PUBLIQUEMENT A LA FACULTE DE MEDECINE DE GRENOBLE*

Le $1^{\text {er }}$ octobre 2015

DEVANT LE JURY COMPOSE DE :

Président du jury :

M. le Professeur Dominique Plantaz

Membres

M. le Professeur Philippe KAHANE, directeur de thèse

M. le Professeur Vincent DES PORTES

Mme le Docteur Fanny DUBOIS-TEKLALI

Mme le Docteur Dorothée VILLE

*La Faculté de Médecine de Grenoble n'entend donner aucune approbation ni improbation aux opinions émises dans les thèses ; ces opinions sont considérées comme propres à leurs auteurs. 
38706 LA TRONCHE CEDEX - France

TEL : $+33(0) 476637144$

FAX : +33(0)4 76637170

Affaire suivie par Marie-Lise GALINDO : sp-medecine-pharmacie@ujf-grenoble.fr

Doyen de la Faculté : M. le Pr. Jean Paul ROMANET

Année 2014-2015

ENSEIGNANTS A L'UFR DE MEDECINE

\begin{tabular}{|c|c|c|}
\hline CORPS & NOM-PRENOM & Discipline universitaire \\
\hline PU-PH & ALBALADEJO Pierre & Anesthésiologie réanimation \\
\hline PU-PH & APTEL Florent & Ophtalmologie \\
\hline PU-PH & ARVIEUX-BARTHELEMY Catherine & chirurgie générale \\
\hline PU-PH & BALOSSO Jacques & Radiothérapie \\
\hline PU-PH & BARRET Luc & Médecine légale et droit de la santé \\
\hline PU-PH & BENHAMOU Pierre Yves & $\begin{array}{l}\text { Endocrinologie, diabète et maladies } \\
\text { métaboliques }\end{array}$ \\
\hline PU-PH & BERGER François & Biologie cellulaire \\
\hline PU-PH & BETTEGA Georges & Chirurgie maxillo-faciale, stomatologie \\
\hline MCU-PH & BIDART-COUTTON Marie & Biologie cellulaire \\
\hline MCU-PH & BOISSET Sandrine & Agents infectieux \\
\hline PU-PH & BONAZ Bruno & $\begin{array}{l}\text { Gastro-entérologie, hépatologie, } \\
\text { addictologie }\end{array}$ \\
\hline MCU-PH & BONNETERRE Vincent & Médecine et santé au travail \\
\hline PU-PH & BOSSON Jean-Luc & $\begin{array}{c}\text { Biostatiques, informatique médicale et } \\
\text { technologies de communication }\end{array}$ \\
\hline MCU-PH & BOTTARI Serge & Biologie cellulaire \\
\hline PU-PH & BOUGEROL Thierry & Psychiatrie d'adultes \\
\hline PU-PH & BOUILLET Laurence & Médecine interne \\
\hline MCU-PH & BOUZAT Pierre & Réanimation \\
\hline PU-PH & BRAMBILLA Christian & Pneumologie \\
\hline PU-PH & BRAMBILLA Elisabeth & Anatomie et cytologie pathologiques \\
\hline MCU-PH & BRENIER-PINCHART Marie Pierre & Parasitologie et mycologie \\
\hline PU-PH & BRICAULT Ivan & Radiologie et imagerie médicale \\
\hline PU-PH & BRICHON Pierre-Yves & Chirurgie thoracique et cardio- vasculaire \\
\hline MCU-PH & BRIOT Raphaël & Thérapeutique, médecine d'urgence \\
\hline PU-PH & CAHN Jean-Yves & Hématologie \\
\hline MCU-PH & CALLANAN-WILSON Mary & Hématologie, transfusion \\
\hline PU-PH & CARPENTIER Françoise & Thérapeutique, médecine d'urgence \\
\hline PU-PH & CARPENTIER Patrick & Chirurgie vasculaire, médecine vasculaire \\
\hline PU-PH & CESBRON Jean-Yves & Immunologie \\
\hline PU-PH & CHABARDES Stephan & Neurochirurgie \\
\hline PU-PH & CHABRE Olivier & $\begin{array}{c}\text { Endocrinologie, diabète et maladies } \\
\text { métaboliques }\end{array}$ \\
\hline PU-PH & CHAFFANJON Philippe & Anatomie \\
\hline PU-PH & CHAVANON Olivier & Chirurgie thoracique et cardio- vasculaire \\
\hline PU-PH & CHIQUET Christophe & Ophtalmologie \\
\hline PU-PH & CINQUIN Philippe & $\begin{array}{l}\text { Biostatiques, informatique médicale et } \\
\text { technologies de communication }\end{array}$ \\
\hline PU-PH & COHEN Olivier & $\begin{array}{l}\text { Biostatiques, informatique médicale et } \\
\text { technologies de communication }\end{array}$ \\
\hline PU-PH & COUTURIER Pascal & Gériatrie et biologie du vieillissement \\
\hline PU-PH & CRACOWSKI Jean-Luc & $\begin{array}{c}\text { Pharmacologie fondamentale, } \\
\text { pharmacologie clinique }\end{array}$ \\
\hline PU-PH & DE GAUDEMARIS Régis & Médecine et santé au travail \\
\hline PU-PH & DEBILLON Thierry & Pédiatrie \\
\hline MCU-PH & DECAENS Thomas & Gastro-entérologie, Hépatologie \\
\hline PU-PH & DEMATTEIS Maurice & Addictologie \\
\hline
\end{tabular}




\begin{tabular}{|c|c|c|}
\hline PU-PH & DEMONGEOT Jacques & $\begin{array}{c}\text { Biostatiques, informatique médicale et } \\
\text { technologies de communication }\end{array}$ \\
\hline MCU-PH & DERANSART Colin & Physiologie \\
\hline PU-PH & DESCOTES Jean-Luc & Urologie \\
\hline MCU-PH & DETANTE Olivier & Neurologie \\
\hline MCU-PH & DIETERICH Klaus & Génétique et procréation \\
\hline MCU-PH & DOUTRELEAU Stéphane & Physiologie \\
\hline MCU-PH & DUMESTRE-PERARD Chantal & Immunologie \\
\hline PU-PH & EPAULARD Olivier & Maladies Infectieuses et Tropicales \\
\hline PU-PH & ESTEVE François & Biophysique et médecine nucléaire \\
\hline MCU-PH & EYSSERIC Hélène & Médecine légale et droit de la santé \\
\hline PU-PH & FAGRET Daniel & Biophysique et médecine nucléaire \\
\hline PU-PH & FAUCHERON Jean-Luc & chirurgie générale \\
\hline MCU-PH & FAURE Julien & Biochimie et biologie moléculaire \\
\hline PU-PH & FERRETTI Gilbert & Radiologie et imagerie médicale \\
\hline PU-PH & FEUERSTEIN Claude & Physiologie \\
\hline PU-PH & FONTAINE Éric & Nutrition \\
\hline PU-PH & FRANCOIS Patrice & $\begin{array}{l}\text { Epidémiologie, économie de la santé et } \\
\text { prévention }\end{array}$ \\
\hline PU-PH & GARBAN Frédéric & Hématologie, transfusion \\
\hline PU-PH & GAUDIN Philippe & Rhumatologie \\
\hline PU-PH & GAVAZZI Gaétan & Gériatrie et biologie du vieillissement \\
\hline PU-PH & GAY Emmanuel & Neurochirurgie \\
\hline MCU-PH & GILLOIS Pierre & $\begin{array}{l}\text { Biostatiques, informatique médicale et } \\
\text { technologies de communication }\end{array}$ \\
\hline PU-PH & GODFRAIND Catherine & $\begin{array}{c}\text { Anatomie et cytologie pathologiques (type } \\
\text { clinique) }\end{array}$ \\
\hline MCU-PH & GRAND Sylvie & Radiologie et imagerie médicale \\
\hline PU-PH & GRIFFET Jacques & Chirurgie infantile \\
\hline MCU-PH & GUZUN Rita & $\begin{array}{l}\text { Endocrinologie, diabétologie, nutrition, } \\
\text { éducation thérapeutique }\end{array}$ \\
\hline PU-PH & HALIMI Serge & Nutrition \\
\hline PU-PH & HENNEBICQ Sylviane & Génétique et procréation \\
\hline PU-PH & HOFFMANN Pascale & Gynécologie obstétrique \\
\hline PU-PH & HOMMEL Marc & Neurologie \\
\hline PU-PH & JOUK Pierre-Simon & Génétique \\
\hline PU-PH & JUVIN Robert & Rhumatologie \\
\hline PU-PH & KAHANE Philippe & Physiologie \\
\hline PU-PH & KRACK Paul & Neurologie \\
\hline PU-PH & KRAINIK Alexandre & Radiologie et imagerie médicale \\
\hline PU-PH & LABARERE José & Epidémiologie ; Eco. de la Santé \\
\hline PU-PH & LANTUEJOUL Sylvie & Anatomie et cytologie pathologiques \\
\hline MCU-PH & LAPORTE François & Biochimie et biologie moléculaire \\
\hline MCU-PH & LARDY Bernard & Biochimie et biologie moléculaire \\
\hline MCU-PH & LARRAT Sylvie & Bactériologie, virologie \\
\hline MCU-PH & LAUNOIS-ROLLINAT Sandrine & Physiologie \\
\hline PU-PH & LECCIA Marie-Thérèse & Dermato-vénéréologie \\
\hline PU-PH & LEROUX Dominique & Génétique \\
\hline PU-PH & LEROY Vincent & $\begin{array}{l}\text { Gastro-entérologie, hépatologie, } \\
\text { addictologie }\end{array}$ \\
\hline PU-PH & LETOUBLON Christian & chirurgie générale \\
\hline PU-PH & LEVY Patrick & Physiologie \\
\hline MCU-PH & LONG Jean-Alexandre & Urologie \\
\hline PU-PH & MACHECOURT Jacques & Cardiologie \\
\hline PU-PH & MAGNE Jean-Luc & Chirurgie vasculaire \\
\hline MCU-PH & MAIGNAN Maxime & Thérapeutique, médecine d'urgence \\
\hline PU-PH & MAITRE Anne & Médecine et santé au travail \\
\hline MCU-PH & MALLARET Marie-Reine & $\begin{array}{c}\text { Epidémiologie, économie de la santé et } \\
\text { prévention }\end{array}$ \\
\hline MCU-PH & MARLU Raphaël & Hématologie, transfusion \\
\hline MCU-PH & MAUBON Danièle & Parasitologie et mycologie \\
\hline PU-PH & MAURIN Max & Bactériologie - virologie \\
\hline MCU-PH & MCLEER Anne & Cytologie et histologie \\
\hline PU-PH & MERLOZ Philippe & Chirurgie orthopédique et traumatologie \\
\hline
\end{tabular}




\begin{tabular}{|c|c|c|}
\hline PU-PH & MORAND Patrice & Bactériologie - virologie \\
\hline PU-PH & MOREAU-GAUDRY Alexandre & $\begin{array}{l}\text { Biostatiques, informatique médicale et } \\
\text { technologies de communication }\end{array}$ \\
\hline PU-PH & MORO Elena & Neurologie \\
\hline PU-PH & MORO-SIBILOT Denis & Pneumologie \\
\hline MCU-PH & MOUCHET Patrick & Physiologie \\
\hline PU-PH & MOUSSEAU Mireille & Cancérologie \\
\hline PU-PH & MOUTET François & $\begin{array}{l}\text { Chirurgie plastique, reconstructrice et } \\
\text { esthétique, brûlogie }\end{array}$ \\
\hline MCU-PH & PACLET Marie-Hélène & Biochimie et biologie moléculaire \\
\hline PU-PH & PALOMBI Olivier & Anatomie \\
\hline PU-PH & PARK Sophie & Hémato - transfusion \\
\hline PU-PH & PASSAGGIA Jean-Guy & Anatomie \\
\hline PU-PH & PAYEN DE LA GARANDERIE Jean-François & Anesthésiologie réanimation \\
\hline MCU-PH & PAYSANT François & Médecine légale et droit de la santé \\
\hline MCU-PH & PELLETIER Laurent & Biologie cellulaire \\
\hline PU-PH & PELLOUX Hervé & Parasitologie et mycologie \\
\hline PU-PH & PEPIN Jean-Louis & Physiologie \\
\hline PU-PH & PERENNOU Dominique & Médecine physique et de réadaptation \\
\hline PU-PH & PERNOD Gilles & Médecine vasculaire \\
\hline PU-PH & PIOLAT Christian & Chirurgie infantile \\
\hline PU-PH & PISON Christophe & Pneumologie \\
\hline PU-PH & PLANTAZ Dominique & Pédiatrie \\
\hline PU-PH & POLACK Benoît & Hématologie \\
\hline PU-PH & POLOSAN Mircea & Psychiatrie d'adultes \\
\hline PU-PH & PONS Jean-Claude & Gynécologie obstétrique \\
\hline PU-PH & RAMBEAUD Jacques & Urologie \\
\hline MCU-PH & RAY Pierre & Génétique \\
\hline PU-PH & REYT Émile & Oto-rhino-laryngologie \\
\hline MCU-PH & RIALLE Vincent & $\begin{array}{l}\text { Biostatiques, informatique médicale et } \\
\text { technologies de communication }\end{array}$ \\
\hline PU-PH & RIGHINI Christian & Oto-rhino-laryngologie \\
\hline PU-PH & ROMANET J. Paul & Ophtalmologie \\
\hline MCU-PH & ROUSTIT Matthieu & $\begin{array}{l}\text { Pharmacologie fondamentale, pharmaco } \\
\text { clinique, addictologie }\end{array}$ \\
\hline MCU-PH & ROUX-BUISSON Nathalie & Biochimie, toxicologie et pharmacologie \\
\hline PU-PH & SARAGAGLIA Dominique & Chirurgie orthopédique et traumatologie \\
\hline MCU-PH & SATRE Véronique & Génétique \\
\hline PU-PH & SAUDOU Frédéric & Biologie Cellulaire \\
\hline PU-PH & SCHMERBER Sébastien & Oto-rhino-laryngologie \\
\hline PU-PH & SCHWEBEL-CANALI Carole & Réanimation médicale \\
\hline PU-PH & SCOLAN Virginie & Médecine légale et droit de la santé \\
\hline MCU-PH & SEIGNEURIN Arnaud & $\begin{array}{l}\text { Epidémiologie, économie de la santé et } \\
\text { prévention }\end{array}$ \\
\hline PU-PH & STAHL Jean-Paul & Maladies infectieuses, maladies tropicales \\
\hline PU-PH & STANKE Françoise & Pharmacologie fondamentale \\
\hline MCU-PH & STASIA Marie-José & Biochimie et biologie moléculaire \\
\hline PU-PH & TAMISIER Renaud & Physiologie \\
\hline PU-PH & TONETTI Jérôme & Chirurgie orthopédique et traumatologie \\
\hline PU-PH & TOUSSAINT Bertrand & Biochimie et biologie moléculaire \\
\hline PU-PH & VANZETTO Gérald & Cardiologie \\
\hline PU-PH & VUILLEZ Jean-Philippe & Biophysique et médecine nucléaire \\
\hline PU-PH & WEIL Georges & $\begin{array}{l}\text { Epidémiologie, économie de la santé et } \\
\text { prévention }\end{array}$ \\
\hline PU-PH & ZAOUI Philippe & Néphrologie \\
\hline PU-PH & ZARSKI Jean-Pierre & $\begin{array}{c}\text { Gastro-entérologie, hépatologie, } \\
\text { addictologie }\end{array}$ \\
\hline
\end{tabular}

Mise à jour le 14 novembre 2014 
Guérir parfois, Soulager souvent, Ecouter toujours.

Louis Pasteur 


\section{Remerciements}

A Monsieur le Professeur Plantaz

Vous me faites l'honneur de présider cette thèse, merci pour vos conseils et votre disponibilité tout au long de ces quatre années d'apprentissage

\section{A Monsieur le Professeur Des Portes}

Vous me faites un immense honneur en jugeant ce travail. Merci pour la qualité de votre enseignement, votre bienveillance et de m'avoir accompagnée dans la voie de la Neuropédiatrie

\section{A Madame le Docteur Dubois-Teklali}

Tu es un vrai modèle pour moi, et c'est un grand honneur de te compter parmi ce jury. Merci pour toutes les connaissances partagées, ton humanité. Tu m'as toujours accompagné et soutenu. Mille mercis.

\section{A Madame le Docteur Ville,}

Tu me fais un très grand honneur en participant à cette soutenance. Merci pour ta disponibilité, ta bienveillance et tout ce que tu m'as appris.

Et enfin, à Monsieur le Professeur Kahane,

Merci pour la confiance que vous m'avez accordé en dirigeant cette thèse. Merci pour votre encadrement, votre accessibilité, vos encouragements. 
Merci à mes parents,

C'est avant tout vous que je dois remercier. Merci pour votre soutien, pour l'éducation que vous m'avez donné, pour tout ce que vous m'avez offert !

Merci à mes petites souns Clémence et Pauline, même pour les chamailleries ;-). Merci pour tous les bons moments passés et à venir !

Merci à toute ma famille : grands parents, parrain, marraine, oncles, tantes, cousins, cousines, qui m'ont soutenu de près ou d'un peu plus loin.

Merci aux copains :

A Anne. Merci d'avoir été là toutes ces années.

A Claire et Marion, les colocs. Merci de m'avoir supporté et d'avoir adouci mon quotidien. Des premières routes chambériennes à Saint Hélène. Merci Gaelle (pour le classement des tartes du self, et me prouver que tout est possible), Camille (pour les repas-monte-moral notamment), Jany, Suzanne, et tous les autres...

Des sentiers Anneciens : oui cette ligne est pour toi Sophie ! et pour les RI ! Merci d'avoir toujours été là, pour les missions commando dans la boue, et pour ce chouette $26^{\text {ème }}$ anniversaire dans l'office des urg ped !

Des chemins Grenoblois, d'ici ou d'ailleurs : Merci Walter, pour le comté, et ces balades des derniers mois qui tombaient à pic. Merci Vanessa, ma siamoise, ta culture du Gout UnIque des gens Nés Nobles Et Sans Soucis mérite une ligne ;-). Merci Elodie et Sally.

Merci au club des pédiatres, à Julie, mon petit rayon de soleil, à Marine, «c'est bon ça ! », à Mumu, avec qui on est jamais déçue, à Marie, pour ton écoute et d'avoir eu la chance d'être ton interne, à Maud, pour cette chouette brève colocation de bureau.

Merci à tous mes co-internes grenoblois, Mélanie (alors, tu préfères les moustiques ou les RI ?), la PP, Angelina et son calme envié ; Laureline, même les lyonnaises (le thé de $17 \mathrm{~h}$, ça me manque Chadia, Estelle et Annabelle !) et puis l'adultologue du lot, Gabriel. Et puis à tous ceux avec qui je n'ai pas eu la chance de travailler directement : Cyril, Morgane... et les autres...

Merci à Thomas et Pierre, sans qui cette thèse n'aurait statistiquement pas existé.

Merci à toutes les équipes paramédicales, et en particulier l'équipe de l'HDJ : Ninie, Pat, Fanny, Corinne, Dalila... Merci pour ces tranches de rires, ces tranches de pleurs, ces tranches de vie.

Merci à l'équipe de Mbouo, qui contribue à faire de moi un bon médecin (ou en tout cas ma définition!). Il n'y a que les montagnes qui ne se rencontrent pas.

Merci à Marie Ange et Hervé, pour votre présence, et toutes ces connaissances partagées.

Merci à Cécile, Laurent, Pascale et Mme Maynard, pour votre bonne humeur, votre disponibilité.

Merci de m'avoir transmis l'amour de la pointe et du bel alpha!

Merci à l'équipe des E.F.S.N., pour toutes ces siestes, toutes ces crises !

Merci à l'équipe Lyonnaise de Neuropédiatrie. Pour votre accueil, pour le rituel du thé, la seule douche de mon internat et tout ce que j'ai pu découvrir et apprendre à vos côtés pendant ces 6 mois.

Merci à tous les autres, à ceux que je n'ai pas cité et qui ont été à mes côtés. 


\section{Table of contents}

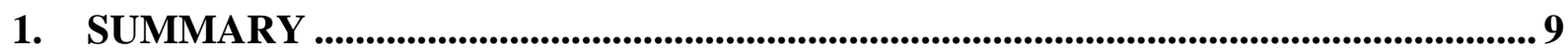

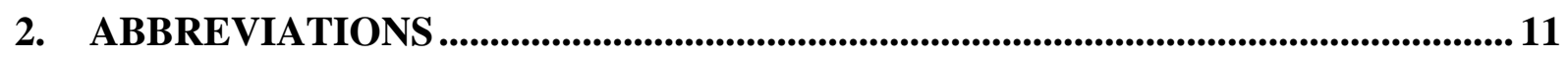

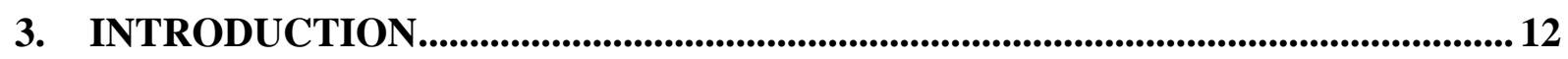

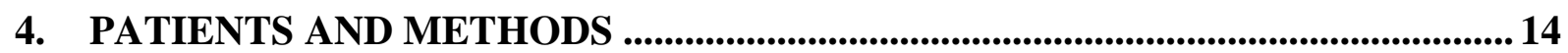

4.1. Selection criteria (Figure 1) ...................................................................................... 14

4.2. Patients's characteristics (Tables 1 and 2) ............................................................... 15

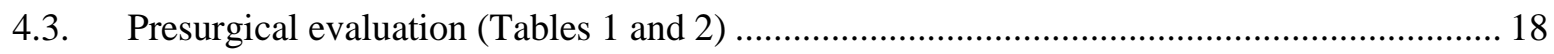

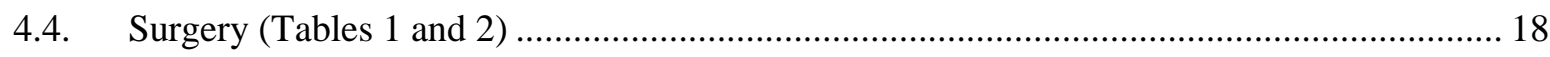

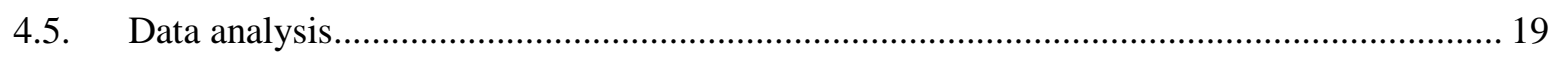

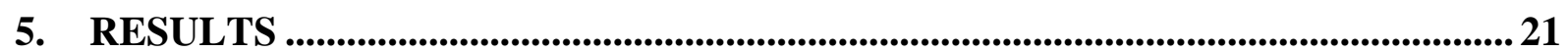

5.1. General clinical features (Table 3) …………………………………………………...... 21

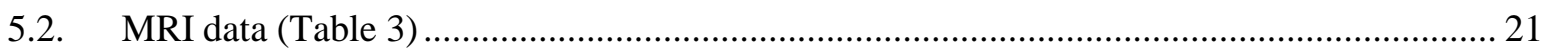

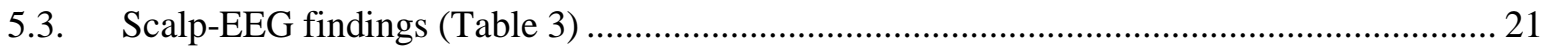

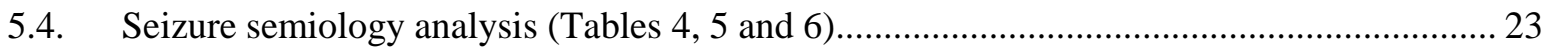

5.5. Literature data (Table 7 and 8) ............................................................................. 27

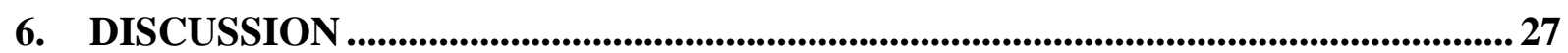

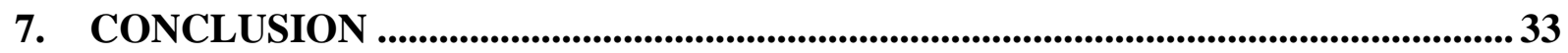

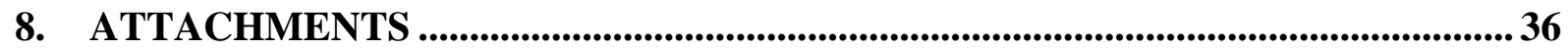

8.1. Attachment 1 : Engel's score (Engel and al., 1993) ......................................................... 36

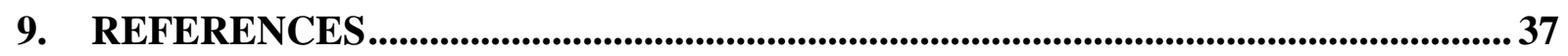

10. SERMENT D'HIPPOCRATE ........................................................................................ 40 


\section{SUMMARY}

Background: Hypermotor seizures (HMS) are characterized by complex movements involving the proximal segments of the limbs and trunk. Seizures frequently begin in childhood, with a nocturnal predominance, high frequency of seizures and possible drug-resistance that can lead to epilepsy surgery. HMS are usually considered to arise from the frontal lobe but recent evidences suggest that they can also arise from other cerebral regions. Thus, their localizing significance remain uncertain, especially in MRI negative cases. Whether there exist anatomoelectro-clinical features that allow to distinguish HMS of frontal origin from HMS of extrafrontal origin remains a crucial issue in epilepsy surgery candidates.

Methods: General features and anatomo-electro-clinical findings were retrospectively reviewed in a cohort of $28 \mathrm{HMS}$ patients who underwent resective/disconnective surgery $(\mathrm{n}=23)$ or radiofrequency thermo-coagulations (RFTC, $n=5$ ) in our center. A SEEG study was performed prior to surgery in 25 cases. Based on surgery location and SEEG data, patients were divided in 2 groups: a 'pure' frontal lobe epilepsy (FLE) group $(n=14)$ and an extra-FLE group $(n=14$, including one temporal case, 5 insular or insulo-opercular cases, and 8 multilobar cases). The main aim of the study was to identify clinical features of seizures that allowed to distinguish the two groups of patients. Whether general clinical features, MRI data, and scalp-EEG recordings were helpful for differentiating the two groups was also evaluated. The two groups were compared using Mann-Whitney T-test for quantitative data and Fisher's test for qualitative data. Significance was set at $\mathrm{p}<0.05$.

Results: The 2 groups of patients were difficult to distinguish based on general features, MRI findings and interictal scalp-EEG abnormalities. However, a few ictal scalp-EEG features and ictal clinical signs significantly differentiate the 2 groups. Ictal scalp EEG more frequently show an anterior frontal onset in the FLE group $(\mathrm{p}=0.01)$, whereas it was more frequently nonlocalizing in extra-FLE patients $(\mathrm{p}=0.016)$. Patients with extra-FLE presented more frequently 
a marked agitation $(\mathrm{p}=0.046)$ and screaming $(\mathrm{p}=0.006)$. They also had more frequently a bimanual/bipedal activity and vegetative signs, although not statistically significant. Patients with FLE had more frequently a short seizure duration $(<30 \mathrm{~s})(\mathrm{p}=0.033)$ and they presented more frequently a bilateral tonic/dystonic posturing, ictal pouting and grasping, but the difference did not reach statistical significance. Seventeen of the 23 patients who had a resective/disconnective surgery, and 1 of the 5 patients who were treated by RFTC became seizure-free (Engel's class I). Results were better in the FLE group (class I: 85.7\%) than in the extra-FLE group (class I: 42.9\%), and the difference was statistically significant ( $\mathrm{p}=0.046)$.

Conclusions: Our data indicate that both ictal scalp-EEG data and a detailed analysis of ictal clinical signs of HMS may help to differentiate HMS of frontal lobe origin from HMS arising from extra-frontal lobe regions among patients contemplating epilepsy surgery. 


\section{ABBREVIATIONS}

DNET: dysembryoplastic neuroepithelial tumour

EEG: electroencephalography

EZ: epileptogenic zone

FCD: focal cortical dysplasia

FLE: frontal lobe epilepsy

GGM: ganglioglioma

HM: hypermotor

HMS: hypermotor seizures

HS: hippocampal sclerosis

ILE: insular lobe epilepsy

MLE: multilobar epilepsy

MRI: magnetic resonance imaging

OAA: oro-alimentary automatisms

PCE: parietal lobe epilepsy

PNES: psychogenic non epileptic seizures

SGTC: secondary generalized tonic-clonic seizures

SEEG: stereo-electroencephalography

SUDEP: sudden unexpected death in epilepsy.

TLE: temporal lobe epilepsy 


\section{INTRODUCTION}

According to the definition proposed by Lüders et al. (1998) and by the International League Against Epilepsy (ILAE) glossary (Blume et al., 2001), hypermotor or hyperkinetic seizures (HMS) are characterized by complex motor movements involving primarily the proximal segments of the limbs and trunk. This results in large-amplitude movements that are frequently relatively explosive and violent. HMS occur in adults as well as in children, although only a few paediatric series have been reported (Weinstock et al., 2003; Sinclair et al., 2004). HMS are often mistaken for psychogenic non epileptic seizures (PNES) or parasomnia, in as much as interictal and/or ictal EEG may prove uninformative (Derry et al., 2009). Seizures predominantly occur during sleep, and their frequency may be very high with a frequent clustering. The clinical pattern is very reproducible in each patient, but widely varies from one patient to another. Seizure semiology mainly includes different forms of complex motor behaviours such as body rocking, pelvic thrusting, pedalling, boxing and kicking (Williamson et al., 1985; Lüders et al., 1998; Provini et al., 1999; Jobst et al., 2000; Blume et al., 2001; Tinuper et al., 2005). Additional motor and non-motor signs may occur, including emotional symptoms, grimacing, vocalizations, tonic/dystonic posturing, and head version (Provini et al., 1999; Jobst et al., 2000; Kotagal et al., 2003; Tinuper et al., 2005). The rate of HMS in focal epilepsies is unknown, but probably low, at least in epilepsy surgery patients where HMS would account for $3 \%$ to $4.5 \%$ of surgically-treated cases (Rheims et al., 2008; Tao et al., 2010; Masuda et al., 2012). Although unfrequent, this seizure type raises important issues in the context of epilepsy surgery, in particular regarding its localizing significance.

HMS have been initially (and continue to be frequently) considered as related to frontal lobe epilepsy (FLE), especially when they occurred during sleep. They have been reported in 1527\% of FLE cases (Swartz et al.,1994; Manford et al., 1996; Jobst et al., 2000; Kotagal et al., 2003 ; Bonini et al., 2014) and can arise from any part of the premotor and prefrontal cortices, 
including the orbito-frontal cortex (Ludwig et al., 1975; Rougier et al., 1988; Chang et al., 1991; Bancaud et al., 1992; Manford et al., 1996; Jobst et al., 2000; Lombroso et al., 2000; Biraben et al., 2001; Bartolomei et al., 2005; Mai et al., 2005; Nobili et al., 2006; Rheims et al., 2008), the anterior cingulate gyrus (Waterman et al., 1987; Biraben et al., 2001; Rheims et al., 2008), the mesial frontal cortex (Penfield and Jasper et al., 1954; Green et al., 1980 ; Kanner et al., 1990; Bancaud et al., 1992; Veilleux et al., 1992; Devinsky et al., 1995; Jobst et al., 2000; Chassagnon et al., 2003; Mai et al., 2005; Nobili et al., 2006 ; Nguyen et al., 2009 ; Tao et al., 2010), the frontal pole (Jobst et al., 2000; Mai et al., 2005; Nobili et al., 2006; Tao et al., 2010), and the dorsolateral frontal cortex (Jobst et al., 2000; Mai et al., 2005; Nobili et al., 2006; Tao et al., 2010). However, and mainly over the last decade, HMS of extra-frontal origin have also been described, including the temporal lobe (Biraben et al., 2001 ; Bartolomei et al., 2002 ; Nobili et al., 2004 ; Carreno et al., 2005 ; Mai et al., 2005 ; Wang et al., 2008 ; Vaugier et al., 2009; Mirandola et al., 2010 ; Tao et al., 2010 ; Masuda et al., 2012), the insula or insulo-opercular cortex (Roper et al., 1993 ; Cukiert et al., 1998 ; Rosetti et al., 2005 ; Kaido et al., 2006 ; Ryvlin et al., 2006, Dobesberger et al., 2008; Zhang et al., 2008; Nguyen et al., 2009; Proserpio et al., 2011, Heers et al., 2012; Dylgjeri et al., 2014) and the parietal lobe (Boesebeck et al., 2002; Nishibayashi et al., 2009; Bartolomei et al., 2011; Fluchère et al., 2012; Montavont et al., 2013; Enatsu et al., 2014). Thus, the localizing value of HMS remain uncertain, which represents a challenging issue especially in MRI negative cases.

We therefore conducted a retrospective study aiming at better delineating the spectrum of HMS in a series of 28 patients who underwent resective/disconective surgery or radiofrequency thermo-coagulations in our center. Since HMS continue to be mainly regarded as arising from the sole FL (and the term "Nocturnal Frontal Lobe Epilepsy" is a good example of such an over-simplification), we used a pragmatic approach and divided the patients in two groups: one where the Epileptogenic Zone (EZ) was located in the frontal lobe only (FLE 
group), and one where the EZ outpassed the limits of the frontal lobe or was located outside the frontal lobe (named extra-FLE group). The main aim of this study was to identify ictal clinical features that could allow to distinguish these two groups of patients. Whether general clinical features, MRI data and scalp-EEG findings were helpful for differentiating the two groups was also evaluated.

\section{PATIENTS AND METHODS}

\subsection{Selection criteria (Figure 1)}

From the database of 682 patients who underwent resective/disconnective surgery or radiofrequency thermo-coagulation (RFTC) for refractory partial epilepsy at our institution between 1990 and 2014, we identified 35 patients who experienced HMS. HMS was defined by ictal complex motor agitation with proximal movements of the limbs, producing irregular sequential ballistic movements such as pedaling, pelvic thrusting, kicking, boxing and rocking movements while lying on the bed (Lüders et al., 1998; Blume et al., 2001). In five of the 35 patients, HMS was not the principal type of seizures so that these patients were not kept for the study. Thus 30 of the 682 patients $(4.4 \%)$ experienced HMS as the main type of seizures, of whom 2 were excluded from analysis because of missing data. The studied population therefore comprised 28 patients, of whom 12 had been previously published either as case reports (Vercueil et al., 1999; Chassagnon et al., 2003) or short series (Ryvlin et al., 2006; Rheims et al., 2008). 
Fig.1 : Flow chart of the study

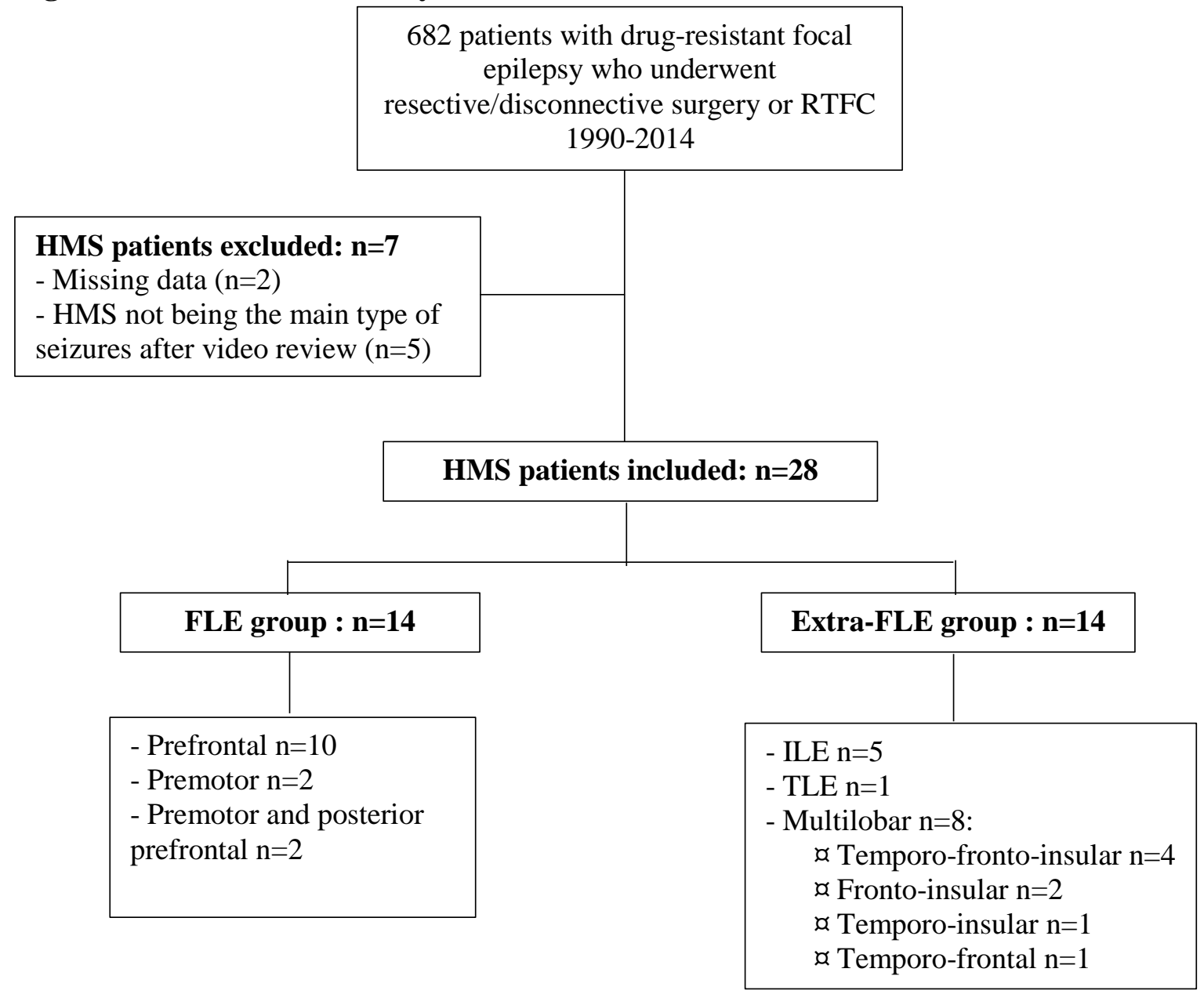

\subsection{Patients's characteristics (Tables 1 and 2)}

The 28 patients comprised 19 males and 9 females, whose mean age at last (in case of 2steps operation) surgery or RFTC was $26.1 \pm 13.1$ years (range 7-53). Mean age at epilepsy onset was $8.7 \pm 6.5$ years (range $0.8-24$ ) with a mean epilepsy duration of $17.3 \pm 11.7$ years (range 3-44). Five patients had a past-history of febrile seizures $(n=2)$ or head trauma $(n=3)$, and 2 had a family history of epilepsy. Seizures frequency ranged from 1 to more than 500 per month (mean: 62.7 per month), with a sleep predominance in 19 patients $(68 \%)$. The clinical presentation of HMS remained constant over time in 17 patients $(61 \%)$, other types of seizures were reported in 13 patients (46\%), and inconstant secondary generalizations occurred in 8 patients $(29 \%)$. MRI was negative in 13 cases $(46 \%)$, whereas it showed different kind of lesions in 15 patients (54\%), including 9 cases of focal cortical dysplasia (FCD). 


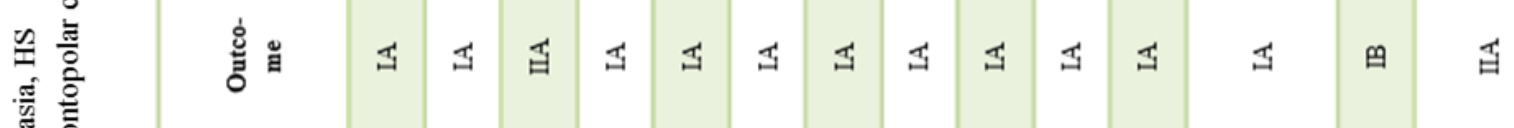

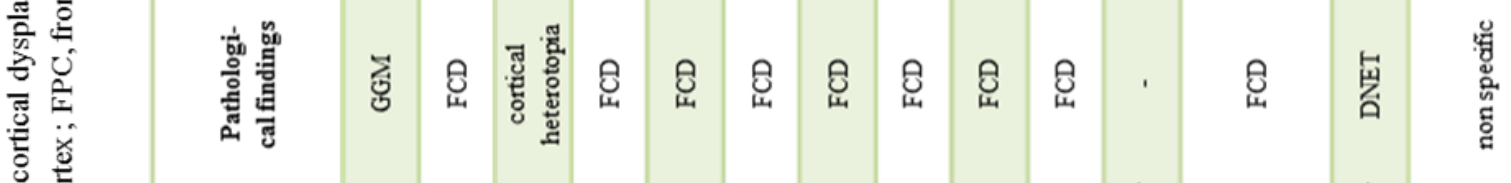

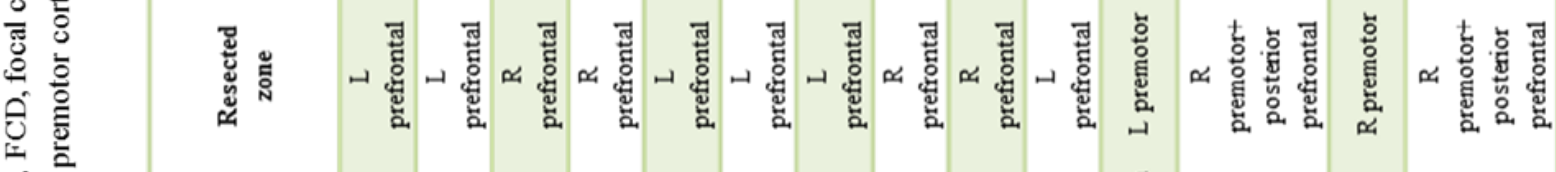

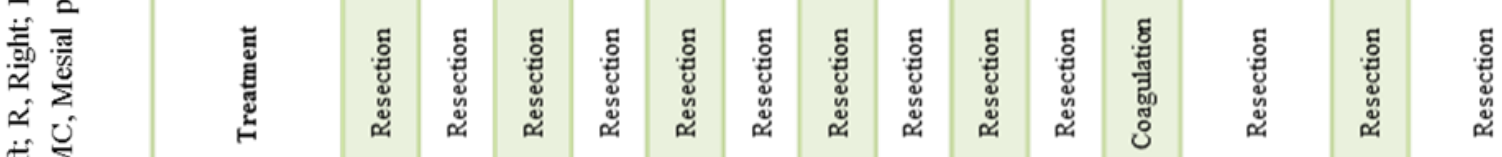

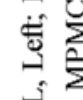

क्षे

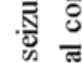

흘

을 它

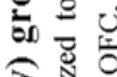

容

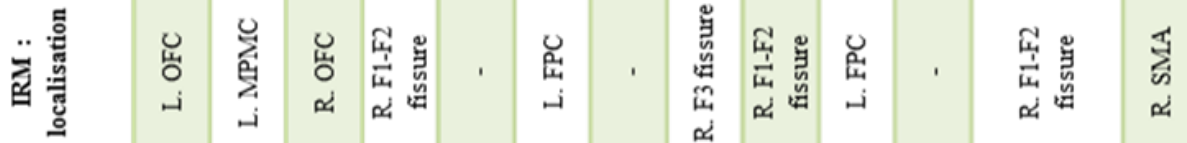

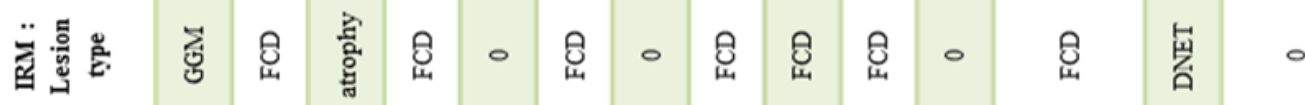

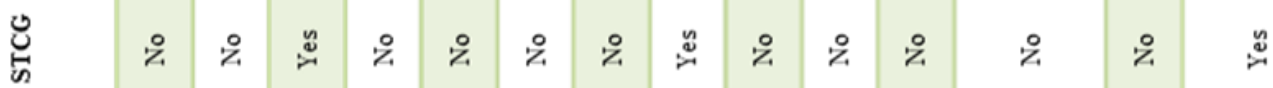

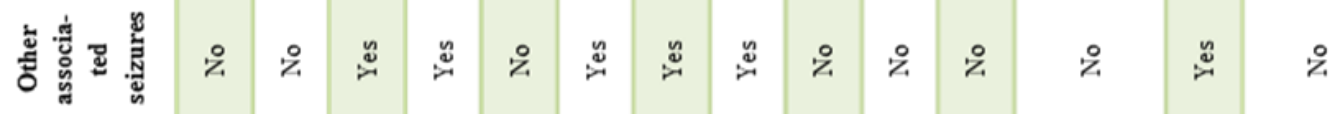

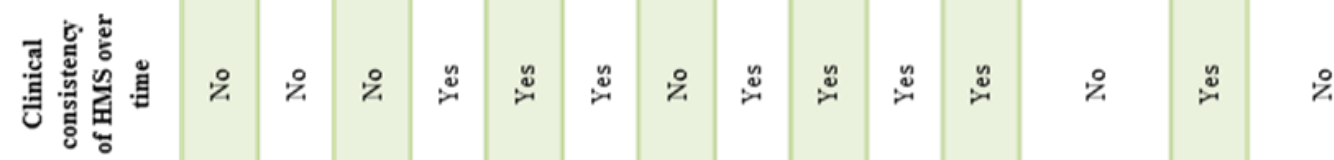

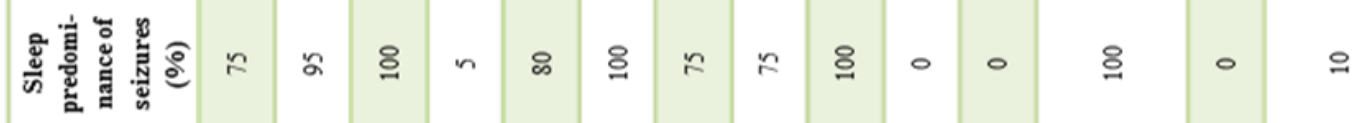

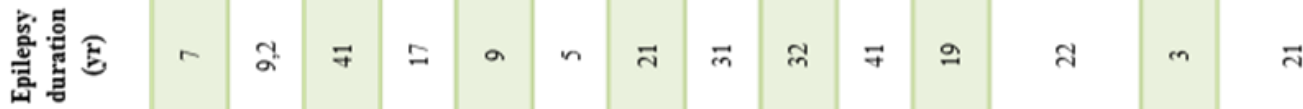

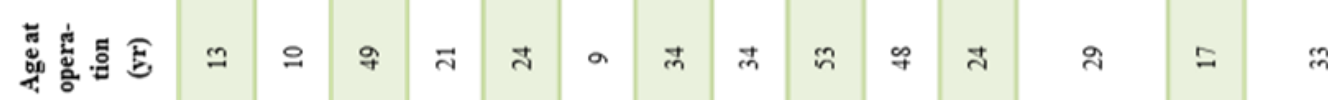

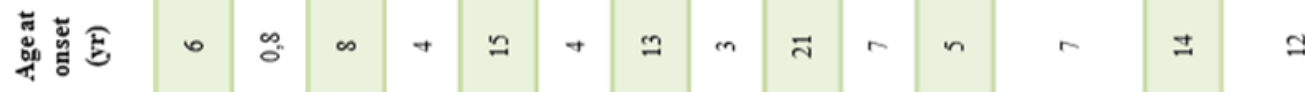
跣 


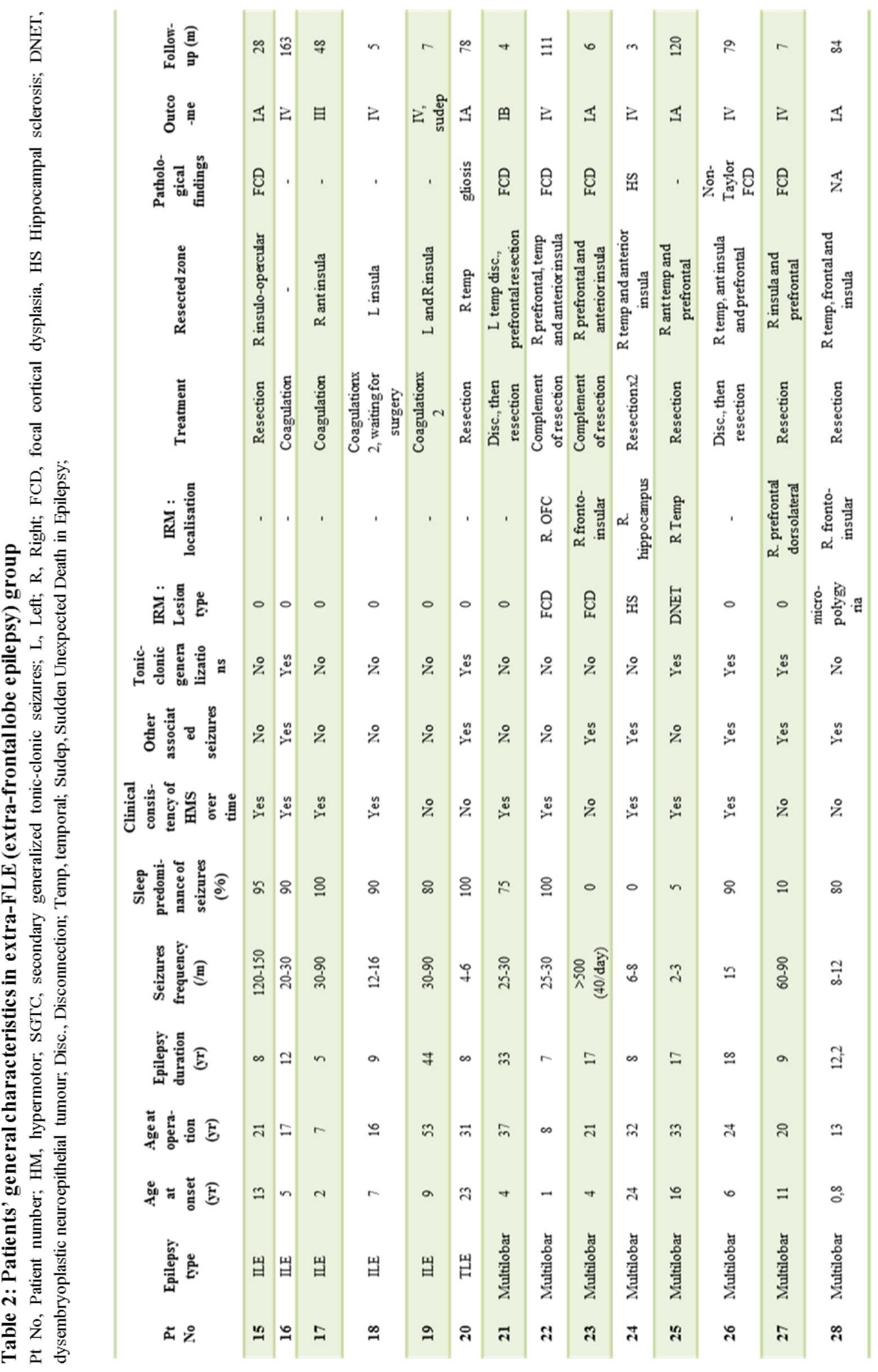




\subsection{Presurgical evaluation (Tables 1 and 2)}

In all the 28 patients, presurgical evaluation included high-resolution MRI, neuropsychological tests and continuous long-term scalp video-EEG monitoring. Based on these data, surgery was considered possible without invasive evaluation in 3 patients (11\%), all suffering from a right FLE (prefrontal: P4, P9; premotor: P13). In the remaining 25 cases (89\%), non-invasive data were considered not sufficiently concordant for localizing the epileptogenic zone (EZ) and video-SEEG recordings were undertaken according to the methodology developed by our group (Kahane et al., 2004). Six of these 25 cases were explored twice (of whom 3 in another center) because the first SEEG study failed to localize correctly the EZ. Following SEEG results, the EZ proved to be right-sided in 13 cases and left-sided in 12 cases. Seizure arose from the frontal lobe in 11 patients (prefrontal: 8, premotor: 1, prefrontal and premotor: 1), from the insular or insulo-opercular cortex in 5 patients, from the temporal lobe in one patient, and from a complex multilobar EZ in 8 patients (temporo-frontal: 2, temporoinsular: 1, fronto-insular: 2, temporo-fronto-insular: 3).

Overall, based on these results, the 28 patients were divided in 2 groups: a 'pure' frontal lobe epilepsy (FLE) group $(n=14)$ and an 'extra'-FLE group $(n=14)$. This latter group included both temporal lobe epilepsy (TLE) and insulo(-opercular) epilepsy (ILE) cases, as well as multilobar epilepsy (MLE) cases, of whom 7 had an EZ encompassing part of the frontal lobe. We acknowledge that including these latter 7 patients in the 'extra'-FLE group raises some issues, in particular regarding the clinical analysis of HMS. These issues have been addressed in the results section and in the discussion.

\subsection{Surgery (Tables 1 and 2)}

Twenty-three of the 28 patients had a resective $(n=23)$ and/or a disconnective $(n=5)$ surgery, of whom 5 were operated twice (previous resection: 3, previous disconnection: 2) 
because the first surgery failed to control the seizures (P21, P22, P23, P24, P26). RFTC were applied within the EZ in the remaining 5 patients, of whom 2 had a very focal EZ (P11, P17) and 3 had an EZ encompassing eloquent areas that made resective surgery too risky (P16, P18, P19). Pathological examination, available for 21 of the 23 the resection procedures, provided an histological diagnosis for all the 15 lesions seen on MRI in these 21 patients, and revealed different kind of lesions in all of the remaining 6 patients in whom MRI was negative. Seizure outcome was assessed according to Engel's classification (Engel et al., 1993). After a mean follow-up after surgery or RFTC of 56.6 months (range 3-204 months), 18 patients were in Engel's class I (64.3\%), 2 in class II (7.1), 1 in class III (3.6\%), and 7 in class IV (25\%) (including one patient - P19 - who died from a SUDEP). Results were better in the FLE group (class I: $85.7 \%$ ) than in the extra-FLE group (class I: $42.9 \%$ ), and the difference was statistically significant $(\mathrm{p}=0.046)$.

\subsection{Data analysis}

To extract potential information allowing to distinguish, non-invasively, patients with frontal HMS (FLE group) from patients with HMS of other location (extra-FLE group), the general clinical and MRI features, scalp-EEG findings and ictal clinical symptology were compared between the 2 groups. The clinical reports detailing scalp-EEG data were used to evaluate the presence/absence of interictal abnormalities (spikes and/or slow waves), their lateralization (unilateral, bilateral) and their localization (according to the 10-20 system). Seizure onset was lateralized and localized similarly. Seizure onset was defined by the occurrence of a fast (beta) activity, clear-cut flattening, or rhythmic (theta) activity, or by the disappearance of focal interictal EEG abnormalities, providing that these changes occurred before the clinical onset of the seizure. Seizure semiology was assessed by reviewing the videotapes of all the seizures recorded during video-EEG and video-SEEG monitoring. Only 
the clinical manifestations that were observed consistently across the seizures were considered as relevant. Seizure duration was evaluated during one typical episode, and calculated from the beginning of the first clinical sign to the clinical end of the fit (cessation of motor manifestations). Seizure semiology was analysed according to a working definition of ictal symptoms, including auras (if any), HM behaviours, other motor signs, and non-motor manifestations (see Tables 4 and 5). The description of HM behaviours was inspired from the one proposed by Rheims et al. (2008), the intensity of the agitation being considered as 'marked' or 'mild' by taking account the amplitude and the speed of the movements. HMS were then classified as type 1 and type 2 HMS, according to the classification proposed by these authors. HMS1 mainly consisted of marked agitation with body rocking, kicking, or boxing, associated with a facial expression of fear and vegetative signs; and HMS2 mainly consisted of mild agitation with horizontal movements or rotation of trunk and pelvis while lying on the bed, usually associated with a tonic/dystonic posturing of the limbs (Rheims et al., 2008). The other ictal clinical manifestations were categorized according to the glossary proposed by the International League Against Epilepsy (ILAE) (Blume et al., 2001).

Statistical analyses were performed using SPSS (v19 and above). All relevant data were compared between patients with FLE and extra-FLE using Mann-Withney test for quantitative data, and Fisher's Exact Test for qualitative data. Significance was set at $\mathrm{p}<0.05$.

In addition, we did a review of the HMS patients in the literature on PubMed database, using "hypermotor seizures" and "hyperkinetic seizures" keywords. Only reports published after 2000 were selected, and reports without details on the semiology of seizures of patient were excluded. 


\section{RESULTS}

\subsection{General clinical features (Table 3 )}

There was no statistical difference between FLE and extra-FLE groups when comparing age at seizure onset, epilepsy duration, seizure frequency, sleep predominance of seizures, clinical pattern consistency of HMS over time, association with other seizure types, and secondary tonic-clonic generalization.

\subsection{MRI data (Table 3)}

MRI proved more frequently informative in the FLE group (71.4\%) than in the extra-FLE group (35.7\%), including the presence of FCD (FLE: 50\%, extra-FLE: 14.3\%). The difference, however, did not reach significance. Interestingly, MRI was negative in all the 5 patients suffering from ILE, as compared with 8 of the other 23 patients suffering from other forms of epilepsy, but the difference was not significant $(\mathrm{p}=0.28)$.

\subsection{Scalp-EEG findings (Table 3)}

Four patients did not exhibit any interictal EEG abnormalities (14.3\%), 3 in the FLE group and one the extra-FLE ( $\mathrm{p}=\mathrm{NS}$ ). No significant differences were found between FLE and extraFLE patients regarding lateralization and localization of interictal abnormalities. The seizure onset was non definable (muscle artifacts) in 2 patients (7.1\%), bilateral in 5 patients (17.9\%) and lateralized in 21 patients (75\%), without significant differences between FLE and extraFLE patients. The first ictal EEG changes, however, were more frequently localized over the anterior frontal region in the FLE group ( $\mathrm{p}=0.03)$. This remained significant when comparing the 14 FLE patients with the 7 MLE involving part of the frontal lobe ( $\mathrm{p}=0.047)$. By opposition, the seizure onset was more frequently non localizing in the extra-FLE group $(\mathrm{p}=0.006)$, and this remained significant when comparing the 7 MLE involving part of the frontal lobe with the 14 FLE $(\mathrm{p}=0.03)$. 
Table 3. General features, MRI findings, and scalp-EEG data of the 28 patients with hypermotor seizures. The patients were divided in two groups: one where the epileptogenic zone (EZ) was located in the frontal lobe only (FLE group, n=14), and one where the EZ outpassed the limits of the frontal lobe or was located outside the frontal lobe (extra-FLE group, $n=14$ ).

\begin{tabular}{|c|c|c|c|}
\hline & FLE $(n=14)$ & Extra-FLE $(n=14)$ & $\mathbf{p}$ \\
\hline \multicolumn{4}{|l|}{ General features } \\
\hline Sex Ratio (male/female) & 1,8 & 2,5 & \\
\hline Age at seizure onset & $8,56 \pm 5,44$ & $8,99 \pm 7,32$ & 0.91 \\
\hline Age at surgery & $28,07 \pm 14.28$ & $23.79 \pm 11,82$ & 0.35 \\
\hline Epilepsy duration & $19,87 \pm 12,66$ & $15.32 \pm 10.38$ & 0.26 \\
\hline Seizure frequency per month & $56,82 \pm 55,86$ & $68,82 \pm 124,64$ & 0.61 \\
\hline Sleep predominance of seizures & 9 & 10 & 1 \\
\hline Clinical consistency of HMS over time & 8 & 9 & 1 \\
\hline Other associated seizures & 6 & 7 & 1 \\
\hline Tonic-clonic generalizations & 3 & 5 & 0.68 \\
\hline \multicolumn{4}{|l|}{ MRI findings } \\
\hline MRI+ & 10 & 5 & 0.13 \\
\hline MRI signs of focal cortical dysplasia & 7 & 2 & 0.10 \\
\hline \multicolumn{4}{|l|}{ Interictal scalp-EEG abnormalities } \\
\hline None & 3 & 1 & 0.60 \\
\hline Bilateral & 4 & 5 & 1 \\
\hline Lateralized & 7 & 8 & 1 \\
\hline Not localized & 2 & 3 & 1 \\
\hline Frontal (FP1-F3-F5, FP2-F4-F8) & 4 & 3 & 1 \\
\hline Temporal (T3-T5, T4-T6) & 1 & 3 & 0.60 \\
\hline Fronto-temporal (FP1-F7-T3, FP2-F4-T4) & 2 & 2 & 1 \\
\hline Fronto-precentral (F3-C3, F4-C4) & 2 & 1 & 1 \\
\hline Centro-parietal (C3-P3, C4-P4) & 0 & 1 & 1 \\
\hline \multicolumn{4}{|l|}{ Seizure onset on scalp-EEG } \\
\hline Non definable & 1 & 1 & 1 \\
\hline Bilateral & 1 & 4 & 0.33 \\
\hline Lateralized & 12 & 9 & 0.38 \\
\hline Non localizing & 0 & 7 & 0.006 \\
\hline Anterior frontal (FP1-F3, FP2-F4) & 7 & 1 & $\mathbf{0 . 0 3}$ \\
\hline Fronto-precentral (F3-C3, F4-C4) & 2 & 1 & 0.33 \\
\hline Fronto-temporal (FP1-F7-T3, FP2-F4-T4) & 3 & 4 & 1 \\
\hline Temporal (F7-T3-T5, F8-T4-T6) & 1 & 0 & 1 \\
\hline
\end{tabular}




\subsection{Seizure semiology analysis (Tables 4,5 and 6 )}

A total of 191 HMS were recorded in the 28 patients (mean: 7 seizures per patient, range 125). Altogether, different types of auras were experienced in most of the patients $(71.4 \%)$, of which digestive auras were the most frequent $(32.1 \%)$. HM behaviors were the most often characterized by a marked agitation $(64.3 \%)$ with a combination of different behaviors during which the patients frequently presented a rotation and horizontal movements of the trunk $(60.7 \%)$, and often rose and sat $(57.1 \%)$. Other motor signs were seen in all but 2 cases $(92.9 \%)$, and consisted the most frequently in tonic/dystonic posturing (53.6\%). Vocalizations were common (64.3\%), as well as changes of facial expression (82.1\%) and vegetative signs $(64.3 \%)$. Consciousness was frequently impaired (67.9\%), and an immediate recovery without post-ictal deficit or confusion was observed in a majority of the cases (67.9\%). Generally, and according to the classification of Rheims et al. (2008), 15 patients had the clinical presentation of HMS1 seizures $(53.6 \%)$ and 13 the clinical presentation of HMS2 seizures $(46.4 \%)$.

Overall, the only statistically significant differences between the two groups were as follows: (i) the seizure duration was shorter $(<30 s)$ in the FLE group than in the extra-FLE group ( $\mathrm{p}=0.033$ ); (ii) the agitation intensity was more frequently mild in the FLE group and marked in the extra-FLE group ( $\mathrm{p}=0.046$ ), although the rate of HMS1 and HMS2 was similar between the 2 groups ( $\mathrm{p}=0.449$ ); (iii) the occurrence of a scream during the events was observed only in the extra-FLE group $(\mathrm{p}=0.006)$. Also, extra-FLE patients exhibited much more frequently bipedal or bimanual activities but the difference with FLE patients did not reach significance $(\mathrm{p}=0.077)$. Interestingly, ictal grasping was significantly associated with the group of the 7 MLE involving part of the frontal lobe when compared with the FLE group (0.025). 


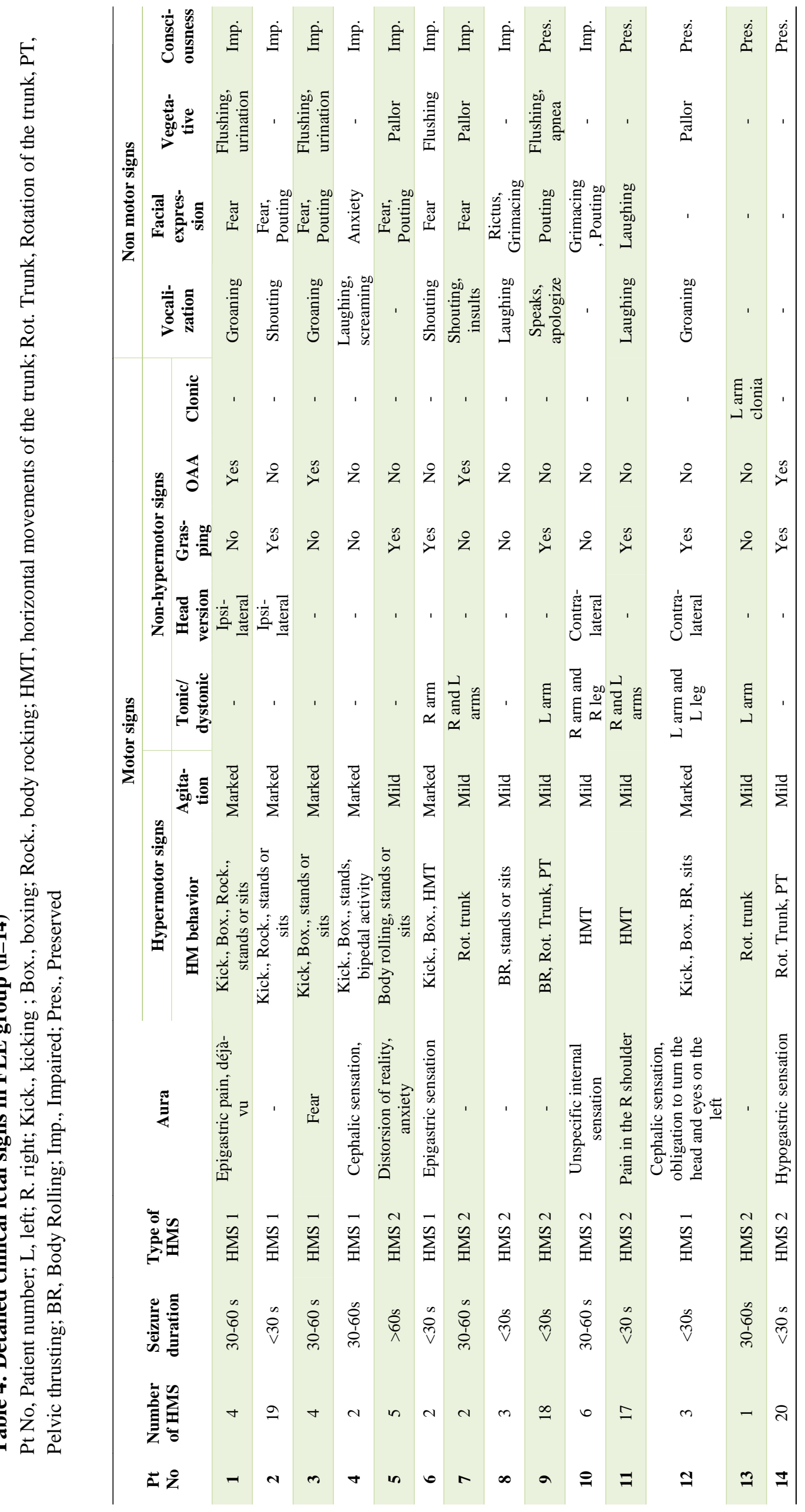




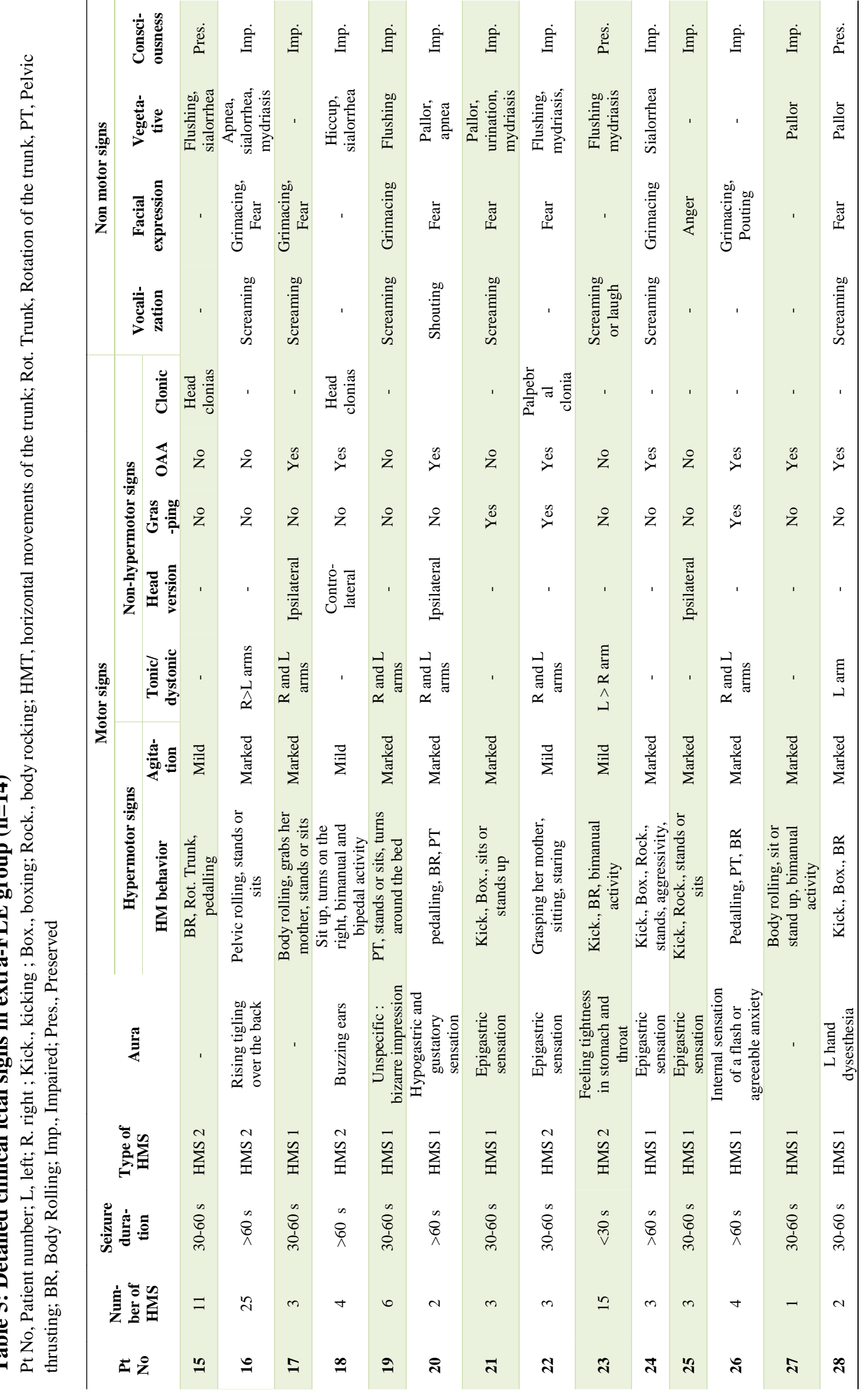


Table 6: Ictal clinical signs in the 28 patients with hypermotor seizures.

Note: More than one sign or behaviour of the same category could coexist in the same individual

\begin{tabular}{|c|c|c|c|c|}
\hline \multirow[b]{2}{*}{ Hypermotor seizures } & \multicolumn{3}{|c|}{ Number of patients presenting the event } & \multirow[b]{2}{*}{$\mathbf{p}$} \\
\hline & $\begin{array}{l}\text { All patients } \\
(\mathbf{n}=\mathbf{2 8})\end{array}$ & $\begin{array}{c}\text { FLE } \\
(n=14)\end{array}$ & $\underset{(n=14)}{\text { Extra-FLE }}$ & \\
\hline \multicolumn{5}{|l|}{ Seizure duration } \\
\hline$<30$ seconds & & 7 & 1 & $\mathbf{0 , 0 3 3}$ \\
\hline Aura & $20(71.4 \%)$ & 9 & 11 & 0,678 \\
\hline None & $8(28.6 \%)$ & 5 & 3 & 0,678 \\
\hline Somatosensory (ipsilateral/contralateral) & $2(7.1 \%)$ & $1(0 / 1)$ & $1(0 / 1)$ & $1(0 / 1)$ \\
\hline Auditory (illusions) & $1(3.6 \%)$ & 0 & 1 & 1 \\
\hline Digestive (throat/abdomen) & $9(32.1 \%)$ & $3(0 / 3)$ & $6(1 / 6)$ & $0,420(1 / 0,420)$ \\
\hline Gustatory & $1(3.6 \%)$ & 0 & 1 & 1 \\
\hline Cephalic & $2(7.1 \%)$ & 2 & 0 & 0,485 \\
\hline Emotional (fear/anxiety/pleasure) & $3(10.7 \%)$ & $2(1 / 1 / 0)$ & $1(0 / 0 / 1)$ & $1(1 / 1 / 1)$ \\
\hline $\begin{array}{l}\text { Other psychic (déjà-vu/distorsion of reality/urge to } \\
\text { move) }\end{array}$ & $3(10.7 \%)$ & $3(1 / 1 / 1)$ & 0 & 0,222 \\
\hline Unspecific & $2(7.1 \%)$ & 1 & 1 & 1 \\
\hline \multicolumn{5}{|l|}{ HM behavior } \\
\hline Kicking, boxing, body rocking & $12(42.9 \%)$ & 6 & 6 & 1 \\
\hline Standing or sitting up & $16(57.1 \%)$ & 7 & 9 & 0,704 \\
\hline Bipedal or bimanual activity & $7(25 \%)$ & 1 & 6 & 0,077 \\
\hline Rotation or horizontal movements of the trunk & $17(60.7 \%)$ & 10 & 7 & 0,44 \\
\hline Body rolling & $10(35.7 \%)$ & 4 & 6 & 0,695 \\
\hline Pelvic thrusting/rolling & $7(25 \%)$ & 2 & 5 & 0,385 \\
\hline \multicolumn{5}{|l|}{ Agitation } \\
\hline Marked & $18(64.3 \%)$ & 6 & 12 & 0,046 \\
\hline Mild & $10(35.7 \%)$ & 8 & 2 & 0,046 \\
\hline Other motor signs & $23(92.9 \%)$ & 2 & 0 & 0.48 \\
\hline Tonic/dystonic posturing (bi-/ipsi-/contralateral) & $15(53.6 \%)$ & $7(2 / 0 / 5)$ & $8(7 / 0 / 1)$ & $1(0,103 / 0 / 0,165)$ \\
\hline Head version (ipsi-/contralateral) & $8(28.6 \%)$ & $4(2 / 2)$ & $4(3 / 1)$ & 1 \\
\hline Grasping & $10(35.7 \%)$ & 7 & 3 & 0,236 \\
\hline Oroalimentary automatisms & $12(42.9 \%)$ & 4 & 8 & 0,252 \\
\hline Vocalization & $18(64.3 \%)$ & 10 & 8 & 0,695 \\
\hline Screaming & $7(25 \%)$ & 0 & 7 & 0,006 \\
\hline Laughing & $3(10.7 \%)$ & 3 & 0 & 0,222 \\
\hline Groaning & $3(10.7 \%)$ & 3 & 0 & 0,222 \\
\hline Shouting & $3(10.7 \%)$ & 3 & 1 & 0,596 \\
\hline Facial expression & $23(82.1 \%)$ & 11 & 12 & 1 \\
\hline Fear & $12(42.9 \%)$ & 6 & 6 & 1 \\
\hline Pouting & $6(21.4 \%)$ & 5 & 1 & 0.16 \\
\hline Grimacing & $7(25 \%)$ & 2 & 5 & 0,385 \\
\hline Vegetative & $18(64.3 \%)$ & 7 & 11 & 0,236 \\
\hline Cardiovascular (flushing/pallor) & $15(53.6 \%)$ & $7(4 / 3)$ & $8(4 / 4)$ & $1(1 / 1)$ \\
\hline Respiratory (apnoea, hiccup) & $4(14.3 \%)$ & $1(1 / 0)$ & $3(2 / 1)$ & $0.596(1 / 1)$ \\
\hline Urination & $3(10.7 \%)$ & 2 & 1 & 1 \\
\hline Sialorrhea & $4(14.3 \%)$ & 0 & 4 & 0.098 \\
\hline Mydriasis & $4(14.3 \%)$ & 0 & 4 & 0.098 \\
\hline Consciousness impairment & $19(67.9 \%)$ & 9 & 11 & 0,678 \\
\hline Postictal phase & $9(32.1 \%)$ & 4 & 5 & 1 \\
\hline \multicolumn{5}{|l|}{ Type of HMS } \\
\hline HMS 1 & $15(53.6 \%)$ & 6 & 9 & 0.449 \\
\hline HMS 2 & $13(46.4 \%)$ & 8 & 5 & 0.449 \\
\hline
\end{tabular}




\subsection{Literature data (Table 7 and 8 )}

We have found on PubMed database 81 cases of FLE with HMS in 8 articles (Bartolomei et al., 2005; Biraben et al.; 2001, Guedj et al., 2012; Masuda et al., 2011; Nguyen et al., 2009; Nobili et al., 2006; Sinclair et al., 2004; Tao et al., 2010), 18 cases of ILE with HMS in 8 articles (Dobesberger et al., 2007; Dylgjeri et al., 2014; Heers et al., 2012; Kaido et al., 2006; Nguyen et al., 2009; Propersio et al., 2011; Zhang et al., 2008); 41 cases of TLE with HMS in 8 articles (Biraben et al., 2001; Guedj et al., 2012; Masuda et al., 2011; Nobili et al., 2004; Tao et al., 2010; Vaugier et al., 2009 ; Wang et al., 2008 ; Yu et al., 2013) ; and 18 cases of PLE with HMS in 5 articles (Nishibayashi et al., 2009; Bartolomei et al., 2011; Enatsu et al., 2014; Guedj et al., 2012; Montavont et al., 2013). Some data were not available (especially about semiology of the seizure and HM behaviour).

\section{DISCUSSION}

The prevalence of HMS is low among drug-resistant epileptic patients, with only 28 patients during a 24 years period at our institution, and 158 cases described in the literature since 2000. Reliability of comparing our cohort and the literature is fragile, due to the small number of patients. General characteristics of all HMS patients of the literature matches with our cohort: paediatric onset $(94.6 \%$, and a mean age at onset of 8.7 years in our cohort), sleep predominance of seizures ( $80.2 \%$ versus $68 \%$ in our cohort), and high frequency of seizures more than 10 by month ( $93.9 \%$ and a mean seizure frequency of 62.7 by month in our cohort). MRI is often uninformative (53.8\% in the literature and $46 \%$ in our cohort). In contrast, all operated patients but one with nonlesional MRI revealed FCD or gliosis on histological examination. There is a high proportion of interictal (72.4\% versus $85.7 \%$ in our cohort) and 


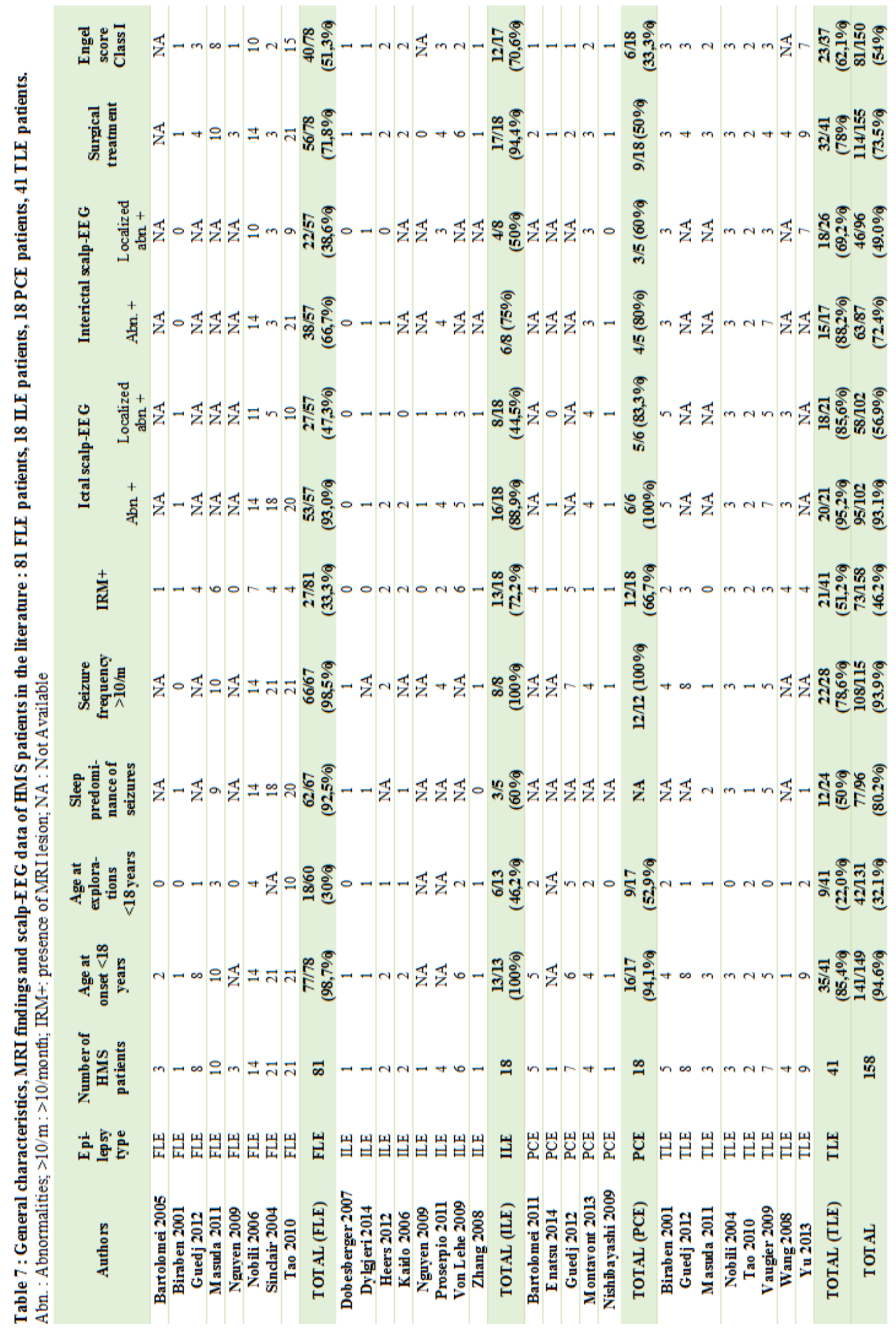




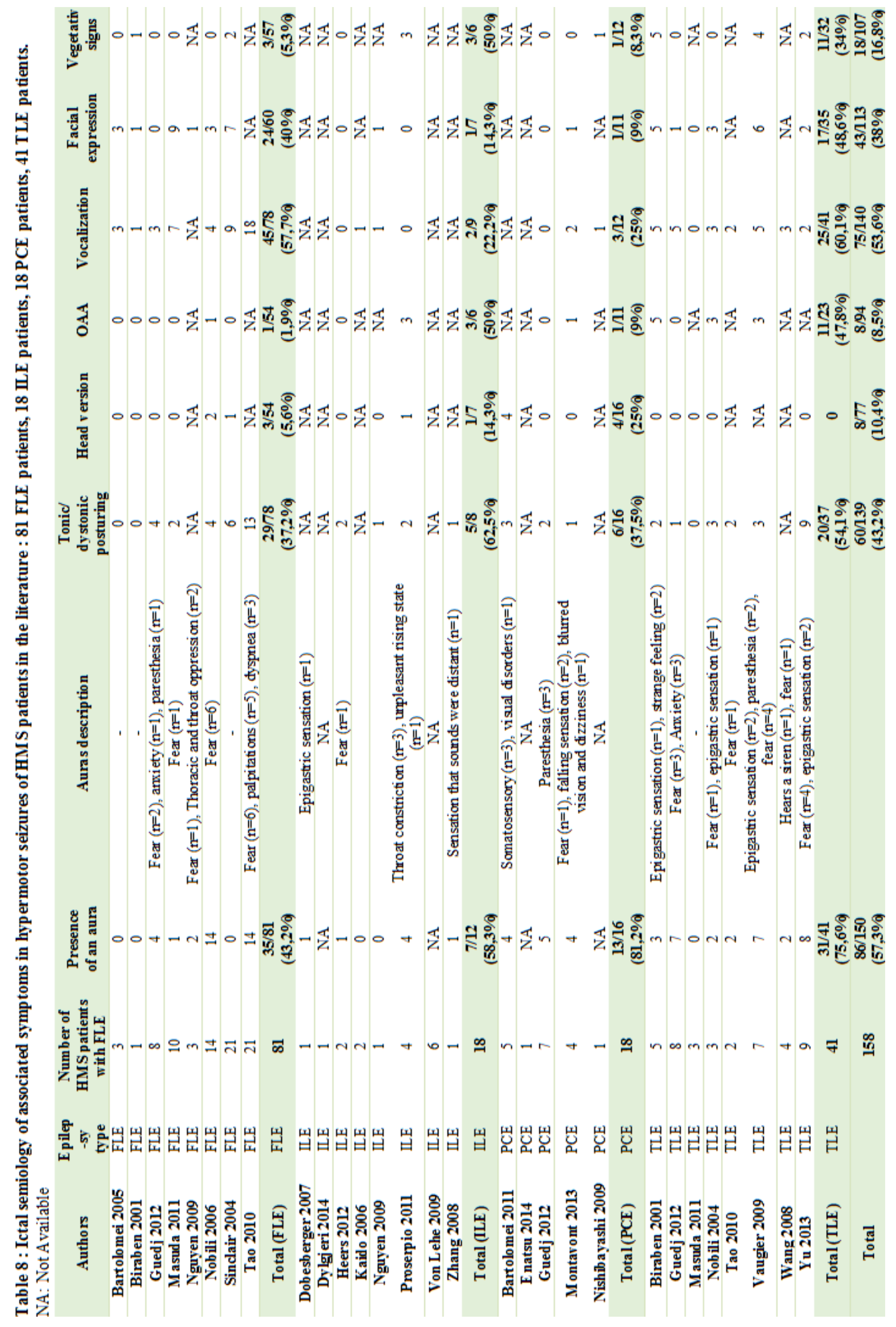


ictal $(93.1 \%$ versus $92.9 \%$ in our cohort) abnormalities, with non-always lateralized and or localized correlations (respectively $56.9 \%$ for ictal and $49 \%$ for interictal abnormalities).

Extreme various patterns of HMS among patients exist, as demonstrated by our series and the literature (with lack of information about detailed HM behaviours). Classifying ictal symptoms in HMS1 and HMS2 (Rheims et al., 2008; Masuda et al., 2012) in our cohort did not permit to find a type of HMS related to a specific lobe onset, but marked agitation (present in HMS1) was statistically more associated with extra-frontal epilepsies. Associated ictal signs might help define different HMS patterns.

HMS from an extra-frontal lobe origin, reported over the last decade, are frequent ( $48.7 \%$ in the literature and $50 \%$ in our cohort). However, only one patient with TLE and none with PCE were treated at our institution during a 24 period of time. In contrary, MLE represented a high proportion of our patients (8 patients), with EZ not always strictly correlated to the MRI lesion. Five of them had an informative MRI, in which two patients had a strictly frontal lesion and two other a fronto-insular lesion. No other study in the literature describes patients with these complicated networks initiating the seizures.

The aim of the present study was to address pragmatically this issue in two groups of patients contemplating for epilepsy surgery; HMS from FLE and extra-FLE implying a different invasive exploration and curative treatment. Our results, although not conclusive, showed that the two groups of patients were difficult to distinguish. General characteristics of FLE and extra-FLE tend to be similar. MRI is an informative non-invasive exam, when a lesion is present. However, a MRI lesion was identified in $72.2 \%$ of ILE patients in the literature, whereas all of our 5 ILE patients had a negative MRI. The incidence of uninformative MRI was 47.6\% in Nobili's report and 73.9\% in Tao's series (Nobili et al., 2007; Tao et al., 2010). Interictal scalp-EEG in FLE showed localized abnormalities in 38.7\% in the literature and 50\% in our series, with predominant fronto-anterior onset. Non localizing ictal onset being frequent 
in extra-FLE (especially in MLE) in our series is hard to confirm by the literature (ictal scalpEEG abnormalities in $44.5 \%$ (ILE) to $85.6 \%$ (PCE)). Scalp-EEG is also often unable to differentiate insular seizures from temporal, posterior, or frontal seizures. (Nguyen et al., 2009).

HM behaviour during the seizure itself is not enough to presume the origin of the seizure. Particular attention must be paid to associated ictal signs: a short duration of seizures being a sign of FLE, marked agitation and screaming being signs of extra-FLE. Aura is a common associated symptom, in whom epigastric sensation is a typical temporal sign (Biraben et al., 2001; Nobili et al., 2004; Vaugier et al., 2009; Yu et al., 2013). In Tao and al 2010, HMS characterized by mild agitation are more associated with asymmetric tonic or dystonic posturing (Tao et al., 2010), and those ictal signs are typical of HMS2 (Rheims et al., 2008). Grasping (present in 7 patients (50\%) of the FLE group, and 3 patients of the extra-FLE group with prefrontal regions involvement) is an almost constant manifestation in frontal hyperkinetic seizures (Gardella et al., 2006).

In our series, outcome after invasive treatment was better in FLE group; with a significant rate of Engel score IV after surgery in extra-FLE group. This information is hard to confirm, other studies essentially being on patients with positive outcome, where EZ was sure. (Rheims et al., 2008; von Lehe et al., 2008). The present study included all HMS patients, seizure free after the treatment or not. In Engel score I patients, we were certain of the epileptogenic zone. In other cases, the EZ was maybe less extensive than the volume of resected tissue in some patients, particularly in those with a multilobar epilepsy. Comparison between FLE and extra-FLE groups is also fragile due to some patients with multilobar epilepsies having an EZ including part of the frontal lobe.

Overall, identifying non-invasively the epileptogenic origin of HMS remains a challenge. Ictal scalp-EEG features and a detailed analyse of the seizures s important. Summary of our findings, which need to be confirm by larger studies, are reported in Figure 2. 
Figure 2 : Pragmatic non invasive characteristics of HMS from FLE and extra-FLE group.

\section{HYPERMOTOR SEIZURES}

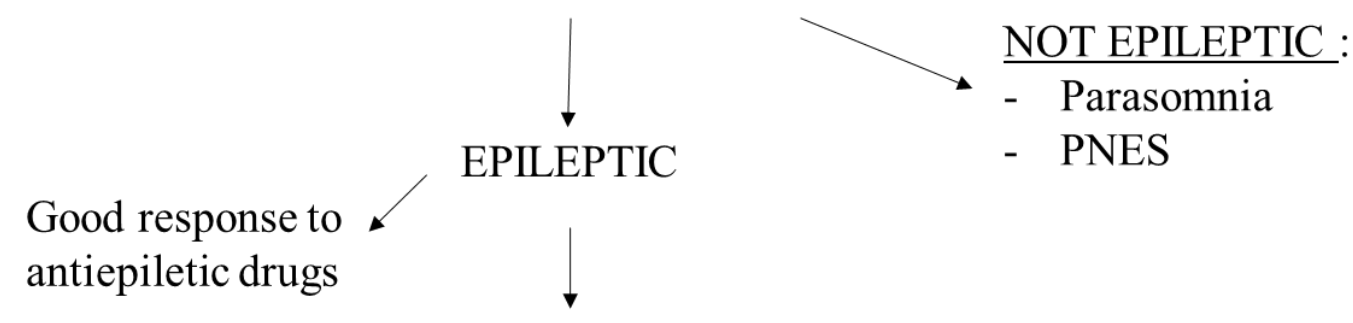

Drug resistant HMS

FLE

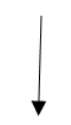

Pediatric onset

General

High frequency of seizure ( $>1$ per day)

features

Nocturnal seizures predominance

Constant seizure pattern during life

\begin{tabular}{|c|c|c|}
\hline MRI & $\begin{array}{l}\text { MRI }+(p=0,13) \\
\text { MRI signs of FCD }(p=0,1)\end{array}$ & MRI - in ILE $(p=0,15)$ \\
\hline EEG & $\begin{array}{l}\text { Fronto-anterior ictal onset } \\
(p=0,03)\end{array}$ & $\begin{array}{l}\text { Non localizing ictal onset } \\
(p=0,006) \\
(\text { especially in multilobar } \\
\text { epilepsy }(p=0,03))\end{array}$ \\
\hline & \multicolumn{2}{|c|}{$\begin{array}{l}\text { Other motors signs } \\
\text { Facial expression (fear, grimacing) }\end{array}$} \\
\hline $\begin{array}{l}\text { Seizure } \\
\text { semio- } \\
\text { logy }\end{array}$ & $\begin{array}{l}\text { Duration of seizures } \\
<30 \text { seconds }(p=0,033) \\
\text { Mild agitation }(p=0,046) \\
\text { Asymetric contralateral } \\
\text { tonic/dystonic posturing } \\
(p=0,165) \\
\text { Pouting }(p=0,16) \\
\text { Grasping }(p=0,236)\end{array}$ & $\begin{array}{l}\text { Marked agitation }(0,046) \\
\text { Screaming }(0,006) \\
\text { Bilateral tonic/dystonic posturing } \\
(p=0,103) \\
\text { Bimanual or bipedal activity } \\
(p=0,077) \\
\text { Vegetative signs }(p=0,236)\end{array}$ \\
\hline
\end{tabular}




\section{CONCLUSION}

Whether there exist anatomo-electro-clinical features that allow to distinguish HMS from frontal or extra-frontal origin remain a crucial issue in epilepsy surgery candidates, especially in those with negative MRI and/or scalp-EEG. General characteristics of patients, MRI results and interictal scalp-EEG of our cohort and the literature were not sufficient. Our data remain to be confirmed by larger studies but indicate that both ictal scalp-EEG data and a detailed analysis of ictal clinical signs of HMS may help to differentiate HMS of frontal lobe origin from HMS arising from extra-frontal lobe regions among patients contemplating epilepsy surgery. 


\section{Thèse soutemue par Elodie LAMETERY}

\section{The spectrum of hypermotor seizures: a pragmatic approach}

\section{CONCLUSION :}

Background: Hypermotor seizures (HMS) are characterized by complex movements involving the proximal segments of the limbs and trunk. Seizures frequently begin in childhood, with a nocturnal predominance, high frequency of seizures and possible drug-resistance that can lead to epilepsy surgery. HMS are usually considered to arise from the frontal lobe but recent evidences suggest that they can also arise from other cerebral regions. Thus, their localizing significance remain uncertain, especially in MRI negative cases. Whether there exist anatomo-electro-clinical features that allow to distinguish HMS of frontal origin from HMS of extra-frontal origin remains a crucial issue in epilepsy surgery candidates.

Methods: General features and anatomo-electro-clinical findings were retrospectively reviewed in a cohort of 28 HMS patients who underwent resective/disconnective surgery $(n=23)$ or radio-frequency thermo-coagulations (RFTC, $n=5$ ) in our center. A SEEG study was performed prior to surgery in 25 cases. Based on surgery location and SEEG data, patients were divided in 2 groups: a 'pure' frontal lobe epilepsy (FLE) group $(\mathrm{n}=14)$ and an extra-FLE group ( $\mathrm{n}=14$, including one temporal case, 5 insular or insuloopercular cases, and 8 multilobar cases). The main aim of the study was to identify clinical features of seizures that allowed to distinguish the two groups of patients. Whether general clinical features, MRI data, and scalp-EEG recordings were helpful for differentiating the two groups was also evaluated. The two groups were compared using Mann-Whitney T-test for quantitative data and Fisher's test for qualitative data. Significance was set at $\mathrm{p}<0.05$.

Results: The 2 groups of patients were difficult to distinguish based on general features, MRI findings and interictal scalp-EEG abnormalities. However, a few ictal scalp-EEG features and ictal clinical signs significantly differentiate the 2 groups. Ictal scalp EEG more frequently show an anterior frontal onset in the FLE group ( $\mathrm{p}=0.03)$, whereas it was more frequently non-localizing in extra-FLE patients $(p=0.006)$. Patients with extra-FLE presented more frequently a marked agitation $(p=0.046)$ and screaming $(p=0.006)$. They also had more frequently a bimanual/bipedal activity and vegetative signs, although not statistically significant. Patients with FLE presented more frequently 
a bilateral tonic/dystonic posturing, pouting and grasping, but the difference did not reach statistical significance. Seventeen of the 23 patients who had a resective/disconnective surgery, and 1 of the 5 patients who were treated by RFTC became seizure-free (Engel's class I). Results were better in the FLE group (class I: 85.7 $\%$ ) than in the extra-FLE group (class I: $42.9 \%$ ), and the difference was statistically significant $(\mathrm{p}=0.046)$.

Conclusions: Our data indicate that both ictal scalp-EEG data and a detailed analysis of ictal clinical signs of HMS may help to differentiate HMS of frontal lobe origin from HMS arising from extra-frontal lobe regions among patients contemplating epilepsy surgery.

VU ET PERMIS D'IMPRIMER

Grenoble, le 8 septembre 2015

LE DOYEN

J.P. ROMANET

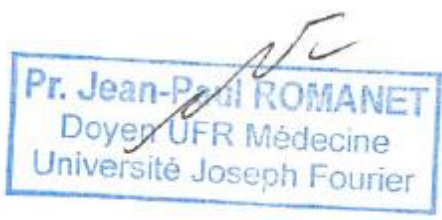

LE PRESIDENT DE LA THESE

PROFESSEUR PLANTAZ

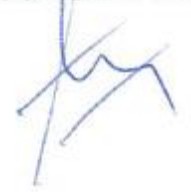




\section{ATTACHMENTS}

8.1. Attachment 1 : Engel's score (Engel and al., 1993)

- Class I - Free of disabling seizures
A: Seizure free
B: Non-disabling SPS only
$\mathrm{C}$ : Free for last two years
D: Convulsions with AED discontinuation only

- Class II - Rare disabling seizures
A: Initially free, rare seizures now
B: Rare disabling seizures
C: Rare last 2 years
D: Nocturnal seizures only

- Class III - Worthwhile improvement
A: Worthwhile seizure reduction
B: Prolonged seizure free periods, not $<2$ years

- Class IV - No worthwhile improvement
A: Significant seizure reduction
B: No appreciable change
C: Seizures worse 


\section{REFERENCES}

Bancaud J, Talairach J. Clinical semiology of frontal lobe seizures. Adv Neurol. 1992;57:3-58.

Bartolomei F, Guye M, Gavaret M, Régis J, Wendling F, Raybaud C, Chauvel P. The presurgical evaluation of epilepsies. Rev Neurol (Paris). 2002 May;158(5 Pt 2):4S55-64.

Bartolomei F, Trébuchon A, Gavaret M, Régis J, Wendling F, Chauvel P. Acute alteration of emotional behaviour in epileptic seizures is related to transient desynchrony in emotion-regulation networks. Clin Neurophysiol. 2005 Oct;116:24739.

Bartolomei F, Gavaret M, Hewett R, Valton L, Aubert S, Régis J, Wendling F, Chauvel P. Neural networks underlying parietal lobe seizures: a quantified study from intracerebral recordings. Epilepsy Res. 2011 ;93:164-76.

Biraben A, Taussig D, Thomas P, Even C, Vignal JP, Scarabin JM, Chauvel P. Fear as the main feature of epileptic seizures. J Neurol Neurosurg Psychiatry. 2001;70:186-91.

Blume WT, Lüders HO, Mizrahi E, Tassinari C, van Emde Boas W, Engel J Jr. Glossary of descriptive terminology for ictal semiology: report of the ILAE task force on classification and terminology. Epilepsia 2001; 42:1212-8.

Boesebeck F, Schulz R, May T, Ebner A. Lateralizing semiology predicts the seizure outcome after epilepsy surgery in the posterior cortex. Brain. 2002;125:2320-31.

Bonini F, McGonigal A, Trébuchon A, Gavaret M, Bartolomei F, Giusiano B, Chauvel P. Frontal lobe seizures: from clinical semiology to localization. Epilepsia. $2014 ; 55: 264-77$.

Carreño M, Donaire A, Pérez Jiménez MA, Agudo R, Quilez A, Rumià J, Villarejo F, Bargalló N, Boget T, Raspall T, Pintor L, Setoain X. Complex motor behaviors in temporal lobe epilepsy. Neurology. 2005;65:1805-7.

Chang CN, Ojemann LM, Ojemann GA, Lettich E. Seizures of fronto-orbital origin: a proven case. Epilepsia. 1991 JulAug;32:487-91.

Chassagnon S, Minotti L, Kremer S, Verceuil L, Hoffmann D, Benabid AL, Kahane P. Restricted frontomesial epileptogenic focus generating dyskinetic behavior and laughter. Epilepsia. 2003;44:859-63.

Cukiert A, Forster C, Andrioli MS, Frayman L. Insular epilepsy. Similarities to temporal lobe epilepsy. Case report. Arq Neuropsiquiatr. 1998;56:126-8.

Derry CP, Harvey AS, Walker MC, Duncan JS, Berkovic SF. NREM arousal parasomnias and their distinction from nocturnal frontal lobe epilepsy: a video EEG analysis. Sleep. 2009 Dec;32:1637-44.

Devinsky O. Ictal head-turning: lateralization and localization. Neurology. 1985;35:616-7.

Dobesberger J, Ortler M, Unterberger I, Walser G, Falkenstetter T, Bodner T, Benke T, Bale R, Fiegele T, Donnemiller E, Gotwald T, Trinka E. Successful surgical treatment of insular epilepsy with nocturnal hypermotor seizures. Epilepsia. 2008;49:159-62.

Dylgjeri S, Taussig D, Chipaux M, Lebas A, Fohlen M, Bulteau C, Ternier J, Ferrand-Sorbets S, Delalande O, Isnard J, Dorfmüller G. Insular and insulo-opercular epilepsy in childhood: an SEEG study. Seizure. 2014 ;23:300-8.

Enatsu R, Bulacio J, Nair DR, Bingaman W, Najm I, Gonzalez-Martinez J. Posterior cingulate epilepsy: clinical and neurophysiological analysis. J Neurol Neurosurg Psychiatry. 2014;85:44-50.

Engel J Jr, Van Ness PC, Rasmussen TB, Ojemann LM. Outcome with respect to epileptic seizures. In Engel J Jr, ed. Surgical treatment of the epilepsies, second edition. New York: Raven Press 1993; 609-21.

Fluchère F, McGonigal A, Villeneuve N, Chauvel P, Bartolomei F. Ictal "hemiballic-like" movement: lateralizing and localizing value. Epilepsia. 2012;53:41-5.

Gardella E, Rubboli G, Tassinari CA. Video-EEG analysis of ictal repetitive grasping in "frontal-hyperkinetic" seizures. Epileptic Disord. 2006 ;8:267-73.

Green JR, Angevine JB, White JC Jr, Edes AD, Smith RD. Significance of the supplementary motor area in partial seizures and in cerebral localization. Neurosurgery. 1980;6:66-75.

Guedj E, McGonigal A, Vaugier L, Mundler O, Bartolomei F. Metabolic brain PET pattern underlying hyperkinetic seizures. Epilepsy Res. 2012;101:237-45. 
Heers M, Rampp S, Stefan H, Urbach H, Elger CE, von Lehe M, Wellmer J. MEG-based identification of the epileptogenic zone in occult peri-insular epilepsy. Seizure. 2012;21:128-33.

Jobst BC, Siegel AM, Thadani VM, Roberts DW, Rhodes HC, Williamson PD. Intractable seizures of frontal lobe origin: clinical characteristics, localizing signs, and results of surgery. Epilepsia. 2000;41:1139-52.

Kaido T, Otsuki T, Nakama H, Kaneko Y. Hypermotor seizure arising from insular cortex. pilepsia. 2006 ;47:1587-8.

Kahane P, Minotti L, Hoffmann D, Lachaux JP, Ryvlin P, Rosenow F, Lüders H.O Invasive EEG in the definition of the seizure onset zone: depth electrodes. In: Rosenow F., Lüders H.O editors. Handbook of Clinical Neurophysiology, Vol. 3. Amsterdam: Elsevier BV; 2004. P. 109-133.

Kanner AM, Morris HH, Lüders H, Dinner DS, Wyllie E, Medendorp SV, Rowan AJ. Supplementary motor seizures mimicking pseudoseizures: some clinical differences. Neurology. 1990;40:1404-7.

Kotagal P, Arunkumar G, hammel J, Mascha E. Complex partial seizures of frontal lobe onset statistical analysis of ictal semiology. Seizure. 2003;12:268-81.

Lombroso CT. Nocturnal paroxysmal dystonia due to a subfrontal cortical dysplasia. Epileptic Disord. 2000 Mar;2:15-20.

Lüders H, Acharya J, Baumgartner C, Benbadis S, Bleasel A, Burgess R, and al. Semiological seizure classification. Epilepsia 1998;39:1006-13.

Ludwig B, Marsan CA, Van Buren J. Cerebral seizures of probable orbitofrontal origin. Epilepsia 1975;16:141-58.

Mai R, Sartori I, Francione S, Tassi L, Castana L, Cardinale F, Cossu M, Citterio A, Colombo N, Lo Russo G, Nobili L. Sleep-related hyperkinetic seizures: always a frontal onset? Neurol Sci. 2005;26 (Suppl 3):S220-4.

Manford M, Fish DR, Shorvon SD. An analysis of clinical seizure patterns and their localizing value in frontal and temporal lobe epilepsies. Brain. 1996;119:17-40.

Masuda H, Shariff E, Tohyama J, Murakami H, Kameyama S. Clinical patterns and pathophysiology of hypermotor seizures: an ictal SPECT study. Epileptic Disord. 2012;14:32-40.

Mirandola L, Badawy RA, Saunders AM, McIntosh A, Berkovic SF, Jackson GD. Clinical features of seizures associated with parahippocampal/inferior temporal lesions compared to those with hippocampal sclerosis. Epilepsia. 2010;51:1906-9.

Montavont A, Kahane P, Catenoix H, Ostrowsky-Coste K, Isnard J, Guénot M, Rheims S, Ryvlin P. Hypermotor seizures in lateral and mesial parietal epilepsy. Epilepsy Behav. 2013 ;28:408-12.

Nguyen DK, Nguyen DB, Malak R, Leroux JM, Carmant L, Saint-Hilaire JM, Giard N, Cossette P, Bouthillier A. Revisiting the role of the insula in refractory partial epilepsy. Epilepsia. 2009;50:510-20.

Nishibayashi H, Ogura M, Taguchi M, Miki J, Uematsu Y, Itakura T. Nondominant parietotemporal cortical dysplasia manifesting as hypermotor seizures. Epilepsy Behav. 2009 ;14:691-5.

Nobili L, Cossu M, Mai R, Tassi L, Cardinale F, Castana L, Citterio A, Sartori I, Lo Russo G, Francione S. Sleep-related hyperkinetic seizures of temporal lobe origin. Neurology. 2004;62:482-5.

Nobili L, Francione S, Mai R, Cardinale F, Castana L, Tassi L, Sartori I, Didato G, Citterio A, Colombo N, Galli C, Lo Russo G, Cossu M. Surgical treatment of drug-resistant nocturnal frontal lobe epilepsy. Brain. 2007;130:561-73.

Penfield W, Jasper WW. (1954) Epilepsy and the functional anatomy of the human brain. Little Brown, Boston.

Proserpio P, Cossu M, Francione S, Tassi L, Mai R, Didato G, Castana L, Cardinale F, Sartori I, Gozzo F, Citterio A, Schiariti M, Lo Russo G, Nobili L. Insular-opercular seizures manifesting with sleep-related paroxysmal motor behaviors: a stereo-EEG study. Epilepsia. $2011 ; 52: 1781-91$.

Provini F, Plazzi G, Tinuper P, Vandi S, Lugaresi E, Montagna P. Nocturnal frontal lobe epilepsy. A clinical and polygraphic overview of 100 consecutive cases. Brain. 1999 Jun; 122:1017-31.

Rheims S, Ryvlin P, Scherer C, Minotti L, Hoffmann D, Guenot M, Mauguière F, Benabid AL, Kahane P. Analysis of clinical patterns and underlying epileptogenic zones of hypermotor seizures. Epilepsia. 2008;49:2030-40.

Roper SN, Lévesque MF, Sutherling WW, Engel J Jr. Surgical treatment of partial epilepsy arising from the insular cortex. Report of two cases. J Neurosurg. 1993;79:266-9.

Rougier A, Loiseau P. Orbital frontal epilepsy: a case report. J Neurol Neurosurg Psychiatry. 1988 Jan;51:146-7. 
Ryvlin P, Minotti L, Demarquay G, Hirsch E, Arzimanoglou A, Hoffman D, Guénot M, Picard F, Rheims S, Kahane P. Nocturnal hypermotor seizures, suggesting frontal lobe epilepsy, can originate in the insula. Epilepsia. $2006 ; 47: 755-65$.

Sinclair DB, Wheatley M, Snyder T. Frontal lobe epilepsy in childhood. Pediatr Neurol. 2004; 30:169-76.

Staack AM, Bilic S, Wendling AS, Scholly J, Kraus U, Strobl K, Bodin F, Zentner J, Steinhoff BJ. Hyperkinetic seizures in patients with temporal lobe epilepsy: clinical features and outcome after temporal lobe resection. Epilepsia. 2011;52:1439-46.

Swartz BE. Electrophysiology of bimanual-bipedal automatisms. Epilepsia. 1994 ;35:264-74.

Tao Y, Guojun Z, Yuping W, Lixin C, Wei D, Yongjie L. Surgical treatment of patients with drug-resistant hypermotor seizures. Epilepsia. 2010;51:2124-30.

Tinuper P, Provini F, Bisulli F, Lugaresi E. Hyperkinetic manifestations in nocturnal frontal lobe epilepsy. Semiological features and physiopathological hypothesis. Neurol Sci. 200526 (Suppl. 3):S210-4.

Vaugier L, Aubert S, McGonigal A, Trébuchon A, Guye M, Gavaret M, Regis J, Chauvel P, Wendling F, Bartolomei F. Neural networks underlying hyperkinetic seizures of "temporal lobe" origin. Epilepsy Res. 2009;86:200-8.

Veilleux F, Saint-Hilaire JM, Giard N, Turmel A, Bernier GP, Rouleau I, Mercier M, Bouvier G. Seizures of the human medial frontal lobe. Adv Neurol. 1992;57:245-55.

Vercueil L, Kahane P, François-Joubert A, Hirsch E, Hoffmann D, Depaulis A, Marescaux C. Basal ganglia involvement in rotational seizures. Epileptic Disord. 1999 Jun;1:107-12.

von Lehe M, Wellmer J, Urbach H, Schramm J, Elger CE, Clusmann H. Insular lesionectomy for refractory epilepsy: management and outcome. Brain. $2009 ; 132: 1048-56$.

Wang L, Mathews GC, Whetsell WO, Abou-Khalil B. Hypermotor seizures in patients with temporal pole lesions. Epilepsy Res. 2008 ;82:93-98.

Waterman K, Purves SJ, Kosaka B, Strauss E, Wada JA. An epileptic syndrome caused by mesial frontal lobe seizure foci. Neurology. 1987 Apr;37:577-82.

Weinstock A, Giglio P, Kerr SL, Duffner PK, Cohen ME. Hyperkinetic seizures in children. J Child Neurol. 2003; 18:51724.

Williamson PD, Spencer DD, Spencer SS, Novelly RA, Mattson RH. Complex partial status epilepticus: a depth-electrode study. Ann Neurol. 1985;18:647-54.

Yu T, Zhang G, Wang Y, Cai L, Zhou X, Du W, Li Y. Surgical treatment of hypermotor seizures originating from the temporal lobe. Seizure. $2013 ; 22: 862-6$.

Zhang H, Yao Q, Zhao X, Jin X, Wang C, Guo H, You Y, Wang H, Gao G. A hypermotor seizure with a focal orbital frontal lesion originating in the insula: a case report. Epilepsy Res. 2008;82:211-4. 


\section{SERMENT D'HIPPOCRATE}

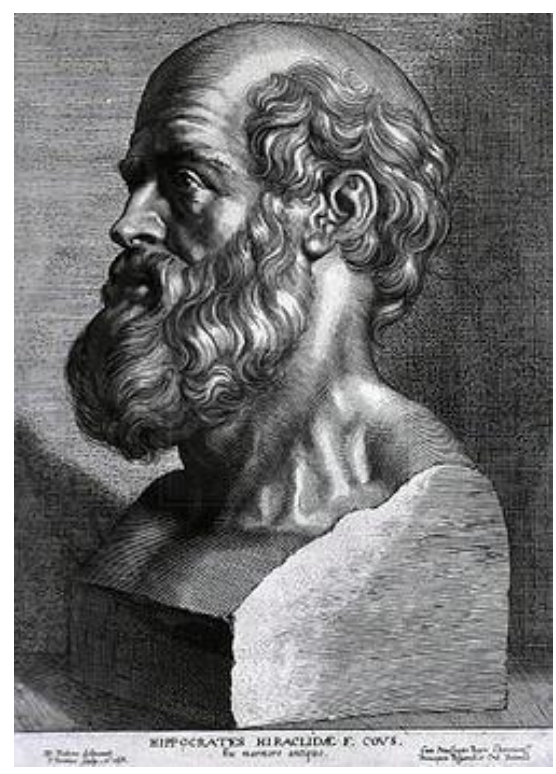

En présence des Maîtres de cette Faculté, de mes chers condisciples et devant l'effigie d'HIPPOCRATE,

Je promets et je jure d'être fidèle aux lois de l'honneur et de la probité dans l'exercice de la Médecine.

Je donnerai mes soins gratuitement à l'indigent et n'exigerai jamais un salaire audessus de mon travail. Je ne participerai à aucun partage clandestin d'honoraires. Admis dans l'intimité des maisons, mes yeux n'y verront pas ce qui s'y passe; ma langue taira les secrets qui me seront confiés et mon état ne servira pas à corrompre les mœurs, ni à favoriser le crime.

Je ne permettrai pas que des considérations de religion, de nation, de race, de parti ou de classe sociale viennent s'interposer entre mon devoir et mon patient. Je garderai le respect absolu de la vie humaine.

Même sous la menace, je n'admettrai pas de faire usage de mes connaissances médicales contre les lois de l'humanité.

Respectueux et reconnaissant envers mes Maîtres, je rendrai à leurs enfants l'instruction que j'ai reçue de leurs pères.

Que les hommes m'accordent leur estime si je suis fidèle à mes promesses.

Que je sois couvert d'opprobre et méprisé de mes confrères si j'y manque. 